This is a pre-copyedited, author-produced PDF of an article accepted for publication in Oxford Economic Papers following peer review. The version of record: Bougheas, $\mathrm{S}$, S, Mizen, P and Silva, S, 2015. The Open Economy Balance Sheet Channel and the Exporting Decisions of Firms: Evidence from the Brazilian Crisis of 1999 Oxford Economic Papers. (In Press.) is available online at: http://oep.oxfordjournals.org/content/early/2015/06/26/oep. gpv046.full. 


\title{
The open economy balance sheet channel and the exporting decisions of firms: evidence from the Brazilian crisis of 1999
}

\author{
By Spiros Bougheas $^{\mathrm{a}}$, Paul Mizen ${ }^{\mathrm{b}}$, and Simone Silva ${ }^{\mathrm{c}}$
}

a School of Economics, University of Nottingham, University Park, Nottingham NG7 2RD; e-mail: spiros.bougheas@nottingham.ac.uk

b School of Economics, University of Nottingham, University Park, Nottingham NG7 2RD; e-mail: paul.mizen@nottingham.ac.uk

c Department of Economics and Finance, Murray State University, Murray, KY 42071, USA;

email: simone.silva@murraystate.edu

\begin{abstract}
We consider the impact of the Brazilian crisis of 1999 on the extensive and intensive margin of exporters versus non-exporters through the open economy balance sheet channel. Using an open-economy balancesheet channel model with firm heterogeneity we explore predictors that firms will engage in global markets. Our results based on a detailed firm-level panel of data for Brazilian 10,573 firms for the period 1996-2007, show that the decision to export and overall growth of sales for exporting firms is driven by size, the debt ratio, the current ratio and operating costs as well as the direct impact of the crisis itself. The findings suggest that the mechanism is driven by the response of the credit market to the creditworthiness of firms as it is by changing terms of trade.
\end{abstract}

JEL: D21, D22, F14, F23 


\section{Introduction}

Historically, financial crises share many similarities (Reinhart and Rogoff, 2009), however, some involve a collapse of the exchange rate regime alone, others involve the banking system and still others combine both elements (twin-crises). Most studies evaluate the aggregate impact of crises by documenting the fiscal costs and lost output growth for the affected countries as a whole following various types of crises, but our paper is different. ${ }^{1}$ We consider how a crisis affects different types of firms within the crisis-affected country, and in particular its impact on exports at the extensive and intensive margins. ${ }^{2}$ By extensive margin we refer to the probability that more firms will export, while the intensive margin refers to the overall growth of total sales of exporting firms. This differs from the conventional measure of the intensive margin based on growth of export sales (which we cannot measure using our data), and requires caution in its interpretation - since growth could result from growing domestic sales as well as growth of exports - but expanding total sales is likely to be consistent with expanding export sales following a crisis. ${ }^{3}$

Our focus is Brazil, where a well-defined currency crisis in 1999 reversed capital flows and depreciated the exchange rate in the aftermath of the East-Asian (1997) and Russian (1998) crises. Capital outflows in Brazil forced the government to float the real on January 1999, depreciating the exchange rate by 47 percent (see Goldfajn, 2000; Collyns and Kincaid, 2003; Goldstein, 2003). Although the central bank raised domestic interest rates to attract FDI inflows, which stabilized the exchange rate, there were consequences of the currency depreciation for exporters and nonexporters. The private sector was partially hedged but externally-oriented firms were more exposed than domestically-oriented ones. We consider the impact of a drastic change in the exchange rate on the performance of exporters and non-exporters. We also consider how tighter financial conditions after the crisis may have influenced exporters depending on the quality of their balance sheets. Many firm-level studies have evaluated export performance after the global financial crisis (c.f. Berman $e t$ al. 2012; Behrens et al. 2013; Manova, 2013) but only the Manova et al. (2014) study of MNC foreign affiliates and joint ventures in China has a comparable focus on emerging economy firmlevel data. Using the SECEX database defining population of exporters in Brazil, we match balance sheets and income statements from Gazeta Mercantil and the Brazilian Institute of

- Eichengreen and Bordo (2003) document 258 crises, 1880-1997, and Allen and Gale (2004) discuss the financial costs of 34 crises, 1977-2000. The average fiscal costs of resolution (percentage of GDP) was $4.5 \%$ for banking crises and $23 \%$ for twin crises. The mean cumulative output loss was $5.6 \%$ and $29.9 \%$ respectively.

Blalock and Roy (2007) use a similar empirical methodology to analyse the behaviour of firms during the Asian crisis. They find that the losses in exports from the extensive margin were compensated by the gains from the intensive margin. Blalock et al. (2008) focus on the advantages of foreign ownership for capital investment. In a firm-level study of the 2001 Argentine crisis Gopinath and Neiman (2011) find that the devaluation had a minor effect on the extensive margin of trade but a strong technological impact due to input readjustment. For the recent 2008 crisis see Chor and Manova (2012).

The impact of the crisis is likely to be in the same direction, but more severe on the domestic market than on export markets because no competitive advantage results from the movement in the exchange rate in domestic sales, but import costs increase. 
Geography and Statistics (IBGE). This allows us to examine the impact of the crisis on exporters and non-exporters due to changes in domestic demand, exchange rates and financial health.

First, we explore the link between these mechanisms and the decision to export at the extensive margin controlling for depreciation in the real exchange rate and the financial health of the corresponding firm. There is a correspondence between our study and the recent literature on firmlevel export responses to variations in the real exchange rate (c.f. Berman et al. 2012 and Behrens et al. 2013). For example, Berman et al. (2012) consider the sensitivity of French firms' exports to movements in the real exchange rate in the pre-financial crisis period, finding that there was considerable heterogeneity in the response of exporters to exchange rate changes.

There is also similarity with Manova (2013) that explores the conditional probability of exporting using a Probit methodology similar to our own. Manova finds that financially advanced nations are more likely to export and the effect is stronger in sectors more dependent on external finance. The results also hold for product variety and numbers of trade partners. Hence credit availability and use have a strong influence over the decision to become an exporter. Credit availability often depends on financial health and collateral assets. We use the variation in the balance sheet characteristics of firms in the pre-crisis and crisis period for exporters and nonexporters to explore the balance sheet channel in Brazil. Greenaway et al. (2007), do something similar by categorising firms into financially constrained or unconstrained using balance sheet variables. ${ }^{4}$ Exporting does not necessarily improve the balance sheets of firms, rather firms with stronger balance sheets, and less binding financial constraints, become exporters. We also confirm that firm financial characteristics such as size, short- and long-run debt ratios, liquidity, current ratio and the cost ratio influence access to finance and the ability of Brazilian firms to export.

Second, we consider the impact on the intensive margin, by assessing the sensitivity of overall sales growth for exporters versus non-exporter at the time of the Brazilian financial crisis of 1999 controlling for differences in the balance sheet characteristics of the two types of firms. We follow the logic of Manova (2013), who argues that access to finance is a key requirement for international trade. She finds strong support for an influence of financial development and external financial dependence on the intensity of exporting. Other studies of the importance of financial factors on margins of trade confirm these views using firm-level panels of data from developing countries (Berman and Héricourt, 2010), and emerging economies (Bigsten et al., 2004, and Rankin et al., 2006). The novelty in our paper is that we consider the population of all exporters in Brazil before and after a financial crisis. Since our paper explores the impact of firm balance sheets on growth in sales there is much in common with dynamic models of export growth and financial constraints such as Besedeš et al. (2014). They find that exporters to the US and Europe face binding credit

\footnotetext{
The standard definition of constrained and unconstrained firms is based on size, dividend, payouts and capital structure (cf. Fazzari et al., 1988, and the survey by Hubbard, 1998).
} 
constraints after a crisis but these are relaxed after approximately three years as firms achieved growth in exports. Together with Muûls (2012) this paper shows that the impact of credit constraints on firms is dynamic rather than static, and varies between firms; we confirm this finding in our study of the intensive margin of exporting in Brazil. Empirically, we look at changes in sales growth for exporting and non-exporting firms, and find sales growth is highly responsive to the balance sheet characteristics of the firm and changes to growth vary with the export- or non-export status of the firm around the time of the crisis.

Comparisons of the relative importance of extensive and intensive margins show the intensive margin is dominant. Behrens et al. (2013) study of Belgian data for exporters in 2008-2009 to consider why trade collapsed during the financial crisis finds the vast majority of the decline in exports was at the intensive margin. There was no reduction in the number of exporting firms due, they argue, to the sunk costs of entering foreign markets. ${ }^{5}$ As the adjustment took place mainly on the intensive margin there was a healthy rebound in exporting when demand picked up. Demand in the destination market was a key determinant of changes to export volumes in their data during the crisis, explaining over half of the fall in exports. Manova (2013) drew a similar conclusion from crosscountry data: between $30-40 \%$ of a reduction in exports from financial development was due to changes at the extensive margin, while $60-70 \%$ was due to reductions at the intensive margin.

The remainder of the paper is organized as follows. In section 2, we present an open economy extension of Holmström and Tirole (1997). This simple model allows us to examine separately the effects of currency depreciation on each of the two margins of international trade and thus provide a useful framework for our empirical work. Section 3 derives the market equilibrium and Section 4 examines firm-level adjustment to a currency crisis. Section 5 outlines our methodology and data before we discuss our results in Section 6, where we consider the exchange rate and the balance sheet channels through which as our model suggests the crisis may affect the extensive and intensive margins of exports. Section 7 concludes.

\section{The model}

We consider a two-sector open-economy model that combines the fixed- and variable-investment versions of Holmström and Tirole (1997). The imposition of fixed outlays will separate firms according to their exporting status and thus, in conjunction with financial constraints, will deliver an extensive margin. The variable investment feature will account for the intensive margin.

\footnotetext{
s There is a large international trade literature that makes a positive link between entry to export markets and firm size through sunk costs; see Bernard et al. (2003), Helpman et al. (2004), Melitz (2003) and Manova (2013). Manova et al. (2014) document that there are additional fixed costs of exporting due to investment in capacity, product customisation, regulatory compliance, and setting up foreign distribution networks. Empirical support for this view is offered in Aw and Hwang (1995), Roberts and Tybout (1997), Aw et al. (2000), Tybout (2003), Bernard and Jensen (2004), Girma et al. (2004) and Greenaway et al. (2007).
} 
There are two countries: a small open economy (domestic economy) and the rest of the world. Let $e$ denote the exchange rate (domestic currency units per unit of foreign currency). In period 0 the government pegs the exchange rate at $e=1$ and agents expect that the peg will be maintained. There is no prior knowledge of a crisis.

There is a continuum of risk-neutral entrepreneurs of unit measure. Each entrepreneur is endowed with one unit of labour and some amount of assets, $A$. The only heterogeneity among entrepreneurs is their endowment of assets, which is distributed on the interval $[0, A]$. F denotes the distribution function and $f$ the corresponding density function.

The economy has two final goods sectors; the output of the first sector is only consumed domestically, while the output of the second sector can either be consumed at home or exported. We label the former 'domestic', and the latter 'exportable', keeping in mind that the actual decision to export is made by the entrepreneur. The inputs used in this economy are sector-specific. The domestic good (numeraire) is produced under a CRS technology whereby production of one unit requires one unit of labour.

The technology for producing the exportable good exhibits increasing returns. It needs to be managed by an entrepreneur who invests physical assets. ${ }^{6}$ The size of start-up capital required depends on whether or not the firm exports. Let $K D$ denote the size of the assets that must be invested by a firm producing only for the domestic market and $K_{x}\left(>K_{D}\right)$ denote the level of investment required by a firm that also exports part of its output. Assets are also used for the purchase of inputs from domestic or foreign sources, which are employed in fixed proportions. Let $p$ denote the fraction of the input from a domestic source. To keep the analysis simple we assume that these inputs are inelastically supplied. One unit of the domestic input costs one unit of assets while the unit cost of the foreign input is equal to one unit of foreign currency. As long as the peg is maintained the domestic currency unit cost of the composite input $c$ is equal to 1.

Following Holmström and Tirole (1997), we assume that the variable investment technology is linear. However, the factor of proportionality is different between exporters and non-exporters. One reasonable interpretation is that the new higher fixed cost, in addition to covering costs related to the establishment of new markets also captures a reorganization of production encouraged by economies of scale related to the simultaneous production of goods for the domestic and foreign markets. To keep the analysis of the demand-side of the model simple we ignore preferences and focus on revenues. While this implies that introducing demand uncertainty is straightforward and allows us to focus on the financial side of the model, it comes at the cost of ignoring currency

\footnotetext{
- Having to allocate time to manage the firm an entrepreneur does not have any available labour for producing the domestic good.
} 
effects on relative prices. ${ }^{7}$ We assume that revenues of the exportable good are stochastic. Thus, with probability $p \mathbf{E}\{p L, p \mathbf{h}\}$ an investment in the composite input of $I$ units yields revenues ${ }_{V} D_{I}$ when the firm produces only for the domestic market and revenues ${ }_{V} X_{I}\left(v X>{ }_{V} D\right)$ when the firm also exports. With probability $1-p$ the investment fails and yields nothing. These shocks are identical and independently distributed across firms.

The probability of success depends on the entrepreneur's effort. Exerting effort raises the probability of success to $p H$ while shirking lowers the probability of success to ${ }_{p} L(<p H)$, however, in the latter case there is an additional benefit, $B I$, which is proportional to the investment level. Let $\mathbf{\Delta}_{p} \mathbf{E}{ }_{p} H-{ }_{p} L$. We assume that when the entrepreneur exerts effort the per unit of investment operating profit is positive, i.e. ${ }_{p} H_{V}$ $>c$, and negative otherwise, i.e. $p L_{V}+{ }_{B}<c$, where $v \mathbf{E}\left\{{ }_{V} D,{ }_{V} X\right\}$. We impose the following restriction on the parameters of the model that ensures that the investment level is finite: ${ }^{8}$

$$
{ }_{p} H(v-\underset{\boldsymbol{\Delta}}{B p})<1 ; \mathbf{h}_{\text {ere } V} \mathbf{E}\{v D, v X\}
$$

All agents must decide which good to produce. Those agents producing the domestic good lend their assets to other entrepreneurs that produce the exportable good, while those agents who produce the exportable good use their assets plus borrowed resources to cover their fixed and variable costs. The second group of agents must also choose between producing only for the home market and producing also for export.

There is a credit market that channels funds from those domestic goods producers to exporters. This market determines the equilibrium gross interest rate, $r$. Assuming limited liability of the borrower the financial contract will specify that the two parties receive nothing when the project fails. Let $R l$ denote the payment to the lender when the project succeeds which implies that the entrepreneur keeps ${ }_{R} b$ E $V I-{ }_{R} l$. Consider an entrepreneur with wealth, $A$, and total investment, $c I+K$. Noting that $v \mathbf{E}\left\{{ }_{V} D, v X\right\}$ and ${ }_{K} \mathbf{E}\left\{{ }_{K} D,{ }_{K} X\right\}$, the lender's zero-profit condition is given by ${ }_{p} H_{R} l=\left(c I+{ }_{K}-{ }_{A}\right) r$ or

$$
{ }_{p} H\left(V I-{ }_{R} b\right)=(c I+K-A) r
$$

This assumes that the contract induces the entrepreneur to exert effort which is ensured by the satisfaction of the incentive compatibility constraint ${ }_{p} H_{R} b \geq{ }_{p} L_{R} b+{ }_{B I}$. The benefit of not shirking is the increase in the expected payoff from ${ }_{p} H_{R} b$ to ${ }_{p} L_{R} b$ while the cost is the loss of the private benefit. We can write the constraints as:

$$
{ }_{R} b \geqq \underline{\Delta B I p}
$$

By substituting (3) into (2) we get an upper bound for the level of investment.

See Berman et al. (2012). Nevertheless, in our empirical work we control for such effects.

As in Holmström and Tirole (1997), when this 6 inequality is not satisfied moral hazard does not have any impact on the ability of firm to raise external funds. 
$* \begin{aligned} & (A-K) r \\ & \\ & c r-p H(V-\triangle B \quad p)\end{aligned}$

Inequality (1) implies that the denominator of (4) is positive. The above inequality suggests that the entrepreneur must have sufficient assets to cover the initial fixed investment, „. Beyond that level borrowing can reach a maximum ${ }_{d} \equiv_{k}-1$ times the level of remaining assets, where ${ }_{k} \equiv$

$r$

$c r-p H(V-\underline{\Delta B} p)$. Any amount above this level violates incentive compatibility in which case the

entrepreneur will not exert effort. Given that lenders make zero profits the entrepreneur's payoff increases in the level of investment, and in equilibrium both (3) and (4) are satisfied as equalities. Thus an entrepreneur with an endowment of assets, „, can borrow an amount ${ } *{ }_{*}-{ }_{\text {A. }}$ 3. Market

\section{equilibrium}

To derive the financial market equilibrium we need to allocate agents to their sector of employment and for those agents who manage firms in the exportable sector we also need a separation between those that produce only for the domestic market and those that also export. We show that those agents with low endowments of assets will produce the domestic good, and those agents with medium level endowments will produce the exportable good but will only be able to sell it in the domestic market while those agents with high endowments will produce the exportable good and sell it both domestically and abroad.

\subsection{Earnings and sector of choice}

The earnings of an agent with an endowment of physical assets, , who becomes an entrepreneur is equal to ${ }_{r} H$. This follows from the fact that in equilibrium the incentive compatibility constraint $B$

$\Delta p$

is binding. The earnings of the same agent who chooses the non-exportable goods sector is equal to $1+\ldots$, which comprises the income from labour plus the return from lending to producers of exportable goods. Setting the above two expressions to be equal (using (4) to substitute for ${ }_{1}$ ) and solving for ${ }_{A}$ we find a threshold level of initial holdings of physical assets $*$ such that all agents with ${ }_{1}>_{1} *$ produce the exportable good and all other agents produce the non-

exportable good. The solution for $*$ is given by

$$
\begin{aligned}
& *=(p H B \Delta p \\
& \quad p H V D-c r)\left(1 r+{ }_{*} D\right)-r 1
\end{aligned}
$$

Condition (1) implies that the expression in the first bracket is bigger than 1 . This implies that the threshold is decreasing in the revenues of the exportable good. It is also increasing in agency costs as measured by $B p$. This is true because as these costs move up the number of agents that can $\Delta$

gain access to external funds decreases. The 
mark-up, 
which indicates the degree to which firms can raise prices above marginal costs due to market power or efficiency of operations. Lastly, the threshold also increases with the market interest rate as a higher rate encourages saving.

\subsection{The choice to export}

Given that the income of an entrepreneur is equal to $p_{H} \frac{B}{\Delta p} I$ we derive the threshold level of assets,

$\sim A$, that separates those that export from those that do not by equating their respective investment levels (by substituting their respective fixed cost and revenue parameters in (4)) and solving for $A$. The solution is:

$$
\begin{aligned}
A^{\sim} & ={ }_{B} \\
& \sim(K x-K D)\left(C r+P H_{A P}\right)+P H(K D V x-K x V D)(6) P I I(V x-V D)
\end{aligned}
$$

Agents with wealth equal to $A$ are indifferent between producing only for the domestic market and also producing exports. In the former case they borrow less given that (a) $K D<K s$, and (b) the investment levels are the same in the two cases, however, in the latter case revenues are higher so that profits in the two cases are the same.

\section{Firm level adjustment to a currency crisis}

Suppose that the government is forced to abandon the exchange rate peg so the exchange rate becomes $e=1+x$ where $x>0$ captures the rate of depreciation. We now consider the immediate and the long-run effects associated with the currency depreciation on contracts signed after the crisis.

\subsection{Immediate effects of the crisis}

Depreciating the currency has an immediate impact on those firms that had signed loan contracts immediately beforehand. ${ }^{9}$ These firms must now purchase foreign inputs at a higher price in domestic currency units. Thus, the total amount of funds used to purchase the composite input is the same, but the number of units purchased equals $j^{*}$, where $c=1+\left(1-(p)_{x}\right.$. Thus, expected revenues decline. All firms that produce goods for the domestic market experience a decline in profits. Given that the obligations of firms to their creditors are unaltered, those firms closer to the threshold, $A^{*}$, might be unable to repay their loans, and might go bankrupt. In contrast, the effect of the depreciation on exporters is ambiguous because, even though they sell less output - which declines because fewer costly inputs can be purchased with a given income - they do so at a higher price in the foreign market. This could result in a higher or a lower profit for the exporter. 
${ }^{3}$ For those firms that managed to hedge their positions in the foreign exchange market the impact would have been less severe.

3.2. The choice to export

Given that the income of an entrepreneur is equal to $\mathrm{pH}$ Al3PI we derive the threshold level of assets, 


\subsection{Long-run effects of the currency depreciation}

Currency depreciation has two direct effects on firms and one indirect effect. It directly affects (a) production costs, since the costs of imported materials rises, and (b) the revenues of exporters, since the value of foreign sales increases after the depreciation. It indirectly affects balance sheets through access to financial markets and rising interest rates, which affects how much manufacturing firms can borrow.

For those firms that produce only for the domestic market the increase in per unit cost implies that investment declines (see (4)). Exporters alone reap the benefits of currency depreciation. Their revenues will now be above $V_{x}$ but less than $(1+x) V_{x}$. The overall effect on their investment depends on the relative effects of depreciation on their costs and revenues.

In order to assess the effect of currency depreciation on access to financial markets we need to consider the two threshold levels of assets that separate (a) those producing exportable goods into those that service both the domestic and the foreign market from those that service only the domestic market, and (b) those that produce exportable goods from those that produce domestic goods. The direct effect of currency depreciation increases the level of the first threshold, $A^{*}$, since

an increase in costs discourages entrepreneurs, while the effect on the second threshold, $\bar{A}$, is ambiguous, since exporters face an increase in both costs and revenues. There is also an indirect effect through the impact of currency depreciation on the equilibrium interest rate.

\subsection{Predictions}

Our model makes the following predictions that we will test in the following sections:

1. Both cut-off values, $A^{*}$ and $A$, rise with an increase in agency costs, therefore the mass of exporting firms decline as agency costs increase.

2. The cut-off value for initial holdings of physical assets sufficient to produce the exportable good, $A^{*}$, is increasing with a currency depreciation (cost effect) and the inverse of the markup (costs, competition and efficiency). Thus, the mass of firms that never export increases.

3. Currency depreciation has an ambiguous effect on the cut-off value for initial holdings of physical assets sufficient to export the good, $\vec{A}$, since exporting firms are less adversely affected by the currency depreciation and might even benefit.

4. Sales growth for non-exporting firms is negatively affected by currency depreciation, and the effect is stronger for firms with poorer balance sheets. For exporting firms the effect is ambiguous as the relative price of exports declines.

First there are predictions about the decision to export at the extensive margin. Our model follows the international trade literature in predicting that larger firms that are also financially 
healthy are more likely to export, and any depreciation of the exchange rate will further encourage exporting.

Movements in the exchange rate can affect both the cost of imported intermediate goods and the value of exports affecting the profitability of firms that sell goods abroad. We expect that the effects of exchange rate fluctuations to depend on whether or not a firm exports. For example, the depreciation of the currency might still boost the incentive to reach foreign markets. We can illustrate this point with reference to data on the movements of the effective exchange rate against the ratio of exporters to total number of industrial firms for the period of our sample in Figure 1.

Second there are predictions relating to the growth in overall sales of firms that export; these sales will increase for larger financially healthy firms that export, and be less affected by a depreciation of the exchange rate. By comparing the performance of exporting firms to the performance of non-exporters we expect exporters to have greater sales. The evidence in Figure 2 shows the ratio of exports to GDP. In the years following the crisis Brazilian firms experienced a rising export ratio and this continued until 2004, by which time the ratio had more than doubled compared to the period before 1999.

The next section explains the methodologies we use to explore the empirical evidence.

\section{Methodology and Data}

\subsection{Empirical methodology}

Our definition of an 'exporter' is based on positive sales outside the domestic market at the firm level, the most disaggregated information we can obtain from our data source. A change occurs at the extensive margin if a firm becomes an exporter, registering positive export sales in total sales for the year, and at the intensive margin if the value of foreign sales increases from one year to the next for a firm that is already exporting. ${ }^{10}$ We do not have information on individual products or export destinations for Brazil from our data source, which we discuss below.

To explore the extensive margin we use Probit estimates of the probability that a firm $i$, in country $j$, will export at time $t$. Our theoretical model indicates that the probability that a firm exports will depend on the scale of the firm, its financial health and the effective exchange rate. As our dependent variable takes values of zero or one, we will initially use a static pooled Probit estimator is clustered on firm ID number to ensure that the estimation of the matrix of variance and covariance allows for intra-firm correlation. The model is:

$$
\begin{aligned}
& \operatorname{Prob}(y=11 x)=i x: 130(t) d t=c 13(x 11)= \\
& c 13\left(13_{0}+\text { lAinTOTAL }_{\text {ASSETS }_{\text {it }}}+13\right. \text { LONG RUN LOANS RATIOu } \\
& +
\end{aligned}
$$

10 For other definitions used in the literature see Besedeš and Prusa (2011, p 372). 
where $\Phi$ represents the cumulative standard normal distribution function. Equation (7) can take into account unobserved heterogeneity in this static framework with the addition of random effects. However, the random effects Probit model requires that firm-specific unobserved effects are uncorrelated with the regressors, which might not hold. The standard alternative in the literature is the fixed effects model. However, since the within transformation for probit does not exist, we estimate equation (7) assuming a linear probability model using fixed effects. Finally, we will estimate a dynamic pooled Probit and dynamic fixed effects model with the addition of a lagged dependent variable to control for the fact that many firms never export, which can create curvature of the regression function close to the values of 0 or 1 .

On the right-hand side, in addition to the effective exchange rate, we have also included the following variables as balance sheet proxies for agency costs. TOTAL ASSETS, defined as total book value of assets (in logarithms) as a proxy for firm size. The LONG-RUN and SHORT-RUN $D E B T$ RATIOS are measures of the ratio of long-run (short-run) debt to total assets, which we use as proxies for agency costs. ${ }^{11}$ The COST RATIO is equal to operational costs divided by revenue used as a proxy for the inverse mark-up ratio. We also use the CURRENT ASSET RATIO, which equals the ratio of current assets to total assets, and the CURRENT RATIO, the current assets over current liabilities to measure access to liquid assets and liabilities.

The model predicts that larger firms will be exporters, since they have sufficient assets to produce and export the good, so we expect a positive sign on the coefficient associated with TOTAL ASSETS. Debt can enable exporting or it can be an adverse signal of agency costs that weighs on a firm's ability to produce exportable goods, or it can limit the firm's ability to raise external funds, therefore we cannot determine a priori the sign of the coefficient associated with our debt ratios. However, a higher value of the COST RATIO is likely to reduce the probability of exporting, and the CURRENT ASSET RATIO tells us that firms have a higher proportion of liquid assets in total assets, making it more likely that they will export. A higher CURRENT RATIO shows that firms have higher assets relative to liabilities Firms with higher current ratios are likely to be less financially constrained, and more likely to be exporters, therefore we expect a positive sign on this variable. ${ }^{12}$ The inclusion of the current asset ratio is in accordance with the free cash-flow theory

\footnotetext{
"Agency costs are associated with debt because when managers accumulate more debt they introduce a potential conflict of interest between owners, managers and lenders; see Myers (1977) and Mello and Parsons (1992).

"Some authors have also added a measure for productivity following Melitz (2003), which underlines its importance of on the extensive and intensive margins, but the evidence in Greenaway et al (2007) specifically with reference to the
} 
according to which agency costs are positively related to excess liquidity and thus negatively related to investment and sales.

We also allow for an exchange rate depreciation to influence the probability of export. We use the real effective exchange rate calculated according to the following formula:

$$
e_{r}=\sum \underset{i}{w i E i}{ }^{*}{ }_{r}
$$

where $P$ is the domestic price index, $P^{*}$ is the price index of the rest of the world, and $E_{i}$ is the nominal exchange rate of trade partner $i$ (expressed in reals per unit of foreign currency) and $w_{i}$ is based on the amount of trade with country $i$. In addition we include macroeconomic variables to allow for variation in demand, relative prices and costs, as well as the crisis dummy=1 in 1999 and zero otherwise, and year effects.

In order to assess if the impact of the crisis was different between exporters and non-exporters we have estimated the following sales growth regression model:

$$
\begin{aligned}
& \text { DL SALESiit } \\
& =130
\end{aligned}
$$

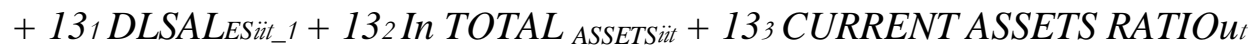

$$
\begin{aligned}
& \text { + 134CURRENT } \text { RATIOüt }+135 \text { COST }_{\text {RATIOit }}+136 L O N G \text { RUN LOANS RATIOut } \\
& \text { + 137SHORT RUN LOANS RATIOU }+ \text { 138CHANGE IN REAL EFFECTIVE EXCHANGE RATE } i_{t} \\
& \text { + 139GDP GROWTHit+1310COMMODITY PRICE GROWTHit + erroriit }
\end{aligned}
$$

The dependent variable is the change in logarithm (sales). While we cannot separate domestic sales from exports, we know total sales for exporters and non-exporters. According to our model, total sales for exporters should be more sensitive to agency costs, scale and the exchange rate. We exercise caution when interpreting growth in total sales as the intensive margin, since growth in sales refers to export and domestic sales. However, in a crisis domestic sales growth is likely to fall as firms gain no competitive advantage from terms of trade but their import costs increase.

Equation (9) can be estimated by either difference GMM or system GMM following the econometric approach of Arellano and Bond (1991), Arellano and Bover (1995) and Blundell and Bond (1998) used by Bond et al. (2003), Bond et al. (2011), Akarım (2013) and Mulkay and Mairesse (2013). The Arellano-Bond estimator differences the variables before using GMM, while the Arellano-Bover and Blundell-Bond estimator improves efficiency by requiring the first differences of instrument variables are uncorrelated with the fixed effects. The addition of further

exporting decision finds "no significant effect" of total factor productivity or labour productivity on the probability of exporting. Greenaway and Kneller (2004) also found at best weak evidence of higher productivity among exporters compared to non-exporters using an unmatched sample of firms, which "disappears" when a matched sample is used. 
equations in levels creates additional moment restrictions improving efficiency, lowering the finite sample bias versus the first difference GMM, and for this reason we prefer to use system GMM.

The validity of the system GMM estimates depends on suitability of the instruments, which we test using a Hansen test for over-identifying restrictions and a second-order serial correlation test suggested by Arellano and Bond (1991). The first test is asymptotically distributed as a chi-square with degrees of freedom corresponding to the number of instruments minus the number of parameters for the null of instrument validity. The second test is asymptotically Normal under the null of no second-order serial correlation. We include dummy variables for industry, year and state, which are exogenous in the "IV-style" (Roodman, 2009), while firm-specific variables that are considered endogenous are incorporated as instruments in the "GMM-style" (Roodman, 2009). The IV approach has been chosen to ensure that we use instruments for variables potentially correlated with the error term. We require at least three consecutive firm-year observations for all firms.

To discriminate between the system- and first-difference GMM estimators we use the difference-in-Hansen statistic (Roodman, 2009), to test the validity of the additional instruments under system GMM. This compares the Hansen test using a full or a sub-set of instruments, and the test statistic is asymptotically chi squared, with degrees of freedom equal to the difference in the number of instruments. If the test is not rejected, system GMM is superior since it conditions for additional (valid) instruments in estimation.

\subsection{Data}

Our data sample 1996-2006 is from three different sources. Data from SECEX covers the full population of exporting firms, ensuring that our data on exporting is representative and complete. ${ }^{13}$ This includes the population of exporters, allowing each firm in each year to be classified as a nonexporter or an exporter all other firms identified by CNPJ (Brazilian firm identification number) are non-exporters. We can obtain firm balance sheets and income statements from Gazeta Mercantil using the CNPJ identifier for each firm. ${ }^{14}$ Other Brazilian data, such as national and industry-level data are provided by IBGE (Brazilian Institute of Geography and Statistics). ${ }^{15}$

We downloaded 52,244 balance sheets from Gazeta Mercantil. After cleaning, the total number of firms that provided total assets, current assets, permanent assets, long-run assets, current liabilities, long-run liabilities, and equity comprises 25,945 balance sheets, but a further 3,190 observations were dropped because of erroneous recordings (e.g. inconsistent balances where total assets are different from total liabilities) or extreme outliers (we removed the top and bottom one percentile of the distribution for each variable). Of the remaining 22,755 observations, only 10,573

\footnotetext{
${ }^{3}$ For more information, see http://www.desenvolvimento.gov.br/sitio/interna/interna.php?area=5\&menu=1444\&refr=603 (last accessed 22/05/15).

"For more information, see http://www.investnews.com.br/ (last accessed 22/05/15).

"See http://www.ibge.gov.br/home/ (last accessed 22/05/15).
} 
have no missing values for any of the variables used in our estimations. More observations were lost when lags were used in the estimations, therefore the number of observations in the Tables differ.

Table 1 provides summary statistics for the firm-level variables. Half of the firms in our sample are exporters. There is considerable variation in the data as can be seen by the considerably large standard errors. There are some very large firms with high asset values, and some small firms. The median firm has US\$18.5mn in total assets of which US\$8mn are current assets. The ratios of short-term and long-term debt to total assets are around 7\% and 6\% of total assets for the median firm, but there are some firms with substantially higher debt ratios.

The second part of Table 1 provides the descriptive statistics for continuing exporters, starters (new exporters), and stoppers (firms that ceased to export). A test of the equality of the means for all three categories (first column, lower panel), shows that most variables are statistically equal, but the change in the log of sales and the current asset ratio differ significantly between groups. Noticeably, growth of sales is positive for starters and continuing exporters but negative for stoppers, and it is significantly different based on F-tests of equality. The liquidity measure (current asset ratio) is lower for stoppers than for the other two groups and once again, there is a significant difference between firms. The differences are less marked between starters and continuing exporters as an Ftest does not reject the null (at 95\% significance) of equality in any category except sales growth in the second column.

The third part of Table 1 provides the descriptive statistics for small and large firms, for exporters and non-exporters, and for small versus large exporters and small versus large nonexporters. Small firms and large firms are defined relative to the median value of the asset distribution of firms in our sample for each year and industry. ${ }^{16}$ Exporters are more prevalent among larger firms, they have lower cost ratios, and are more liquid. Differences are evident between small exporters and small non-exporters as well as between large exporters and large nonexporters.

\section{Results}

\subsection{Evidence on the Extensive Margin}

Table 2 presents the results of the Probit estimations reporting the estimated coefficients and the marginal effects of the variables on the probability of export. We report results for a static pooled Probit model, a random effects Probit model, a linear probability model with fixed effects, a dynamic pooled Probit and a dynamic fixed effects model as discussed in section 5.1. To control for possible endogeneity we report results using the first lag of all variables. Before we discuss the

\footnotetext{
"The findings are not significantly affected when we use alternative cut-off values at the $33^{\text {rd }}$ and $66^{\text {th }}$ percentile.
} 
firm-specific effects in detail, we mention the impact of variables that influence all firms: the change in the real effective exchange rate raises the probability of exporting a little (similar to Berman et al., 2012), while the crisis itself decreases it. Demand effects measured by GDP growth in the rest of the world increase the probability of being an exporter (as they do in Behrens et al., 2013), and higher commodity prices reduce it by a small amount. These are consistent with our initial assumptions.

We now turn to the coefficients associated with asset size, short-term and long-term loan ratios, and liquidity measures; we find they have signs predicted by the model and are strongly significant. In Table 2, an increase in asset size results in a higher probability of export. Although small, the relationship between the lenders' export decisions and their asset size is entirely consistent with the theory and other evidence on access to export markets reported in Roberts and Tybout (1997), Berman and Héricourt (2010), Bernard et al. (2003), Tybout (2003), Bernard and Jensen (2004), Girma et al. (2004), Helpman et al. (2004), Rankin et al. (2006) and Greenaway et al. (2007. propose that size may be a proxy for some time-invariant firm characteristic that drives exporting e.g. access to skilled labour, but it could equally be a proxy for 'access to finance' given the critical role of information inefficiencies, Beck et al. (2009). The domestic focus of small firms' activities compared to the international export focus of larger firms makes size important to lenders in open economy credit channel models. There are fewer incentives for financial intermediaries to lend to small firms but greater incentives to lend to large firms since they are more diversified financially and when they have access to global markets they have exposure to markets at different phases of the business cycle, stabilising cash flow and credit provision (Campa and Shaver, 2002).

There is a small positive effect from higher short-term debt ratios, which is weakly significant, but long-term debt ratios have no effect on exporting. To the extent that debt matters, firms that can obtain external finance have higher debt capacity and lower external financial constraints (Fazzari et al., 2000; Berman and Héricourt, 2010), and are more likely to export. There is other evidence from developing and developed countries that tighter financial constraints are imposed on non-exporters versus exporters (see Campa and Shaver, 2002; Harrison and McMillan, 2003; Berman and Héricourt, 2010; Muûls 2012). In our case the influence of debt ratios is weak as far as the extensive margin is concerned.

Our paper produces other interesting findings. Liquidity is an important determinant of the extent of export sales. A $1 \%$ increase in the current asset ratio increases the probability of exporting by 0.37 (column 1) in the log-linear pooled Probit model, which demonstrates liquidity has a large positive impact on the probability of exporting. It may indicate that liquid assets can be pledged as collateral (Fazzari and Petersen, 1993); or that a high level of liquid assets mitigates agency costs. It might have a similar interpretation to the cash-flow measure used by Bond et al. (2003), Berman 
and Héricourt (2010) and Forlani (2011). ${ }^{17}$ The coefficient associated with the current ratio has a small negative effect on exporting (-0.013) in the pooled Probit model. ${ }^{18}$

Surprisingly, the cost ratio, which reflects the power to raise price above marginal cost, has no significant impact on the probability of exporting. While costs might be expected to vary with the degree of competition that firms face and may raise the threshold for exporting, they have little impact on the extensive margin.

When we make allowance for unobserved heterogeneity, using random effects in a Probit model or fixed effects in a linear probability model (columns 2 and 3), we find similar results to those discussed above. The random effects Probit coefficients in column 2 are an order of magnitude larger than those reported in column 1, but still show positive and significant influence of size and liquidity on the probability of exporting. The results for the marginal effects of the fixed effects linear probability model in column 3 are smaller than column 1 but of the same order of magnitude.

The dynamic models (columns 4 and 5) report coefficients very similar in magnitude to the static pooled Probit and fixed effects linear probability models - size and liquidity measures have a positive marginal effect on the probability of exporting. The major difference in these models is the introduction of a control for firms that are already exporting using a dummy for exporter status in the previous period. The coefficient associated with this dummy is positive and significant, showing strong persistence in the exporter decision (see also Muûls, 2012). Clearly, firms that become exporters tend to remain exporters, suggesting there are few reversions once exporting has begun possibly due to the importance of sunk costs; our results indicate that some balance-sheet variables such as size and liquidity continue to significantly increase the probability of a non-exporter becoming an exporter.

\subsection{Evidence on the Intensive Margin}

Table 3 presents the total sales growth regression results related to our investigation of the intensive margin estimated using system-GMM. According to our model we would expect to see some differences between exporters and non-exporters, especially during a period of exchange rate fluctuations, therefore, we first estimate coefficients for the full sample (column 1), we then consider sub-samples of data for exporters and non-exporters separately (columns 2 and 3) and for exporters and non-exporters separately interacted with the post-crisis dummy (columns 4 and 5).

\footnotetext{
Note that current assets over total assets is a ratio that reflects stocks not flows. Cash flow is a flow measure of the resources available to the firm. They are not directly comparable despite similar interpretations on the coefficients we obtain from different regressions.

"The two variables are not correlated (corr coeff $=0.014$ ). The first illustrates the value of liquid assets in total assets while the second indicates the extent to which firms face limited access to external finance.
} 
Finally, we use the full sample with interactions for exporter and post-crisis dummy and Export Status*Crisis interaction (columns 6 and 7).

Firm size (log of total assets) has a positive and significant influence on the intensive margin for exporters and non-exporters, though the magnitude is smaller for exporters. In a later comparison of small versus large firms in Table 4, we find that larger firms are less sensitive to size than small firms, which is in accordance with Caballero and Hammour (1994) who note smaller firms grow faster. Larger firms are more likely to be exporters due to the requirement for external finance and the ability to absorb exchange rate fluctuations in their markups (see Berman et al., 2012, Besedeš et al. 2014).

The current asset ratio (current assets in total assets) has a strongly positive and significant effect on sales growth regressions in all columns of Table 3 just as it did in Table 2. In general, using sub-sample information we find non-exporters are more sensitive to this indicator than exporters as revealed by a comparison of columns 2 and 3 (without crisis interactions) and columns 4 and 5 (with crisis interactions). Sales growth responds nearly one-for-one with the current asset ratio for non-exporters, while for exporters an increase in this ratio raises growth by between 60-70 percent. Bond et al. (2003) argue that there is bi-directional causality between cash flow, investment and sales growth, with lags of each variable being able to predict the current values of the other variables. This suggests that cash flow measures and real activity measures such as sales growth are interrelated at the firm level, although the intensity varies across countries. As we argued earlier, liquid assets may relax financial constraints for firms that have growth options, and more so for firms that have limited availability of external finance. We confirm the positive and significant effect of current asset ratio on sales growth found by Bond et al. (2003). Our other measure of liquidity is the ratio of current assets to current liabilities (the current ratio). This is almost uncorrelated with the current asset ratio, and given that we have controlled for liquidity already, it has a small but significantly negative effect on sales growth. These findings are consistent with the prediction of our model that lower agency costs will increase sales growth as firms expand exports.

In contrast to our results for the extensive margin reported in Table 2, we find the cost ratio influences the intensive margin. The cost ratio reflects both the competitive environment facing the firm and its operational efficiency which tends to influence the intensity of exports, lifting sales growth. Behrens et al. (2013) note that most adjustment occurs at the intensive margin in response to significant shocks, due to the presence of fixed costs of export participation, and the above result confirms this. Lower costs improve competitiveness and increase sales directed to exports compared to the home market. 
The remaining balance sheet variables in Table 3 show some significance. Higher short-term debt depresses sales, while higher long-term debt ratios have a significant positive influence on sales growth. If a firm tests the waters by carrying more short-term debt it would explain the negative effect of short-term debt. A higher long-term debt ratio is consistent with greater exporting in our model. The coefficient associated with the current ratio is negative for the same reasons discussed in Table 2.

Finally, we allow for the crisis=1 in 1999 and zero otherwise, exporter status and interactions between our variables and these two dummies (column 7). Therefore we can separate the crisis effect, other year effects and macroeconomic influences arising from changes in demand, competitiveness and prices or costs. The crisis has a significant negative effect on export intensity as expected. For exporter status, our model predicts that competitiveness gains would be greater after the crisis compared to non-exporting firms and this is what we find in columns 2-5. The constant in the regression is large, negative and significant for non-exporters and smaller, negative and insignificant for exporters (columns 2 and 3, and 4 and 5). Finally, interacting the exporter status with the crisis we find positive effects of greater size, long-term loans, and higher liquidity are intensified in the crisis (the sum of coefficients is larger), and only costs are moderated by the crisis. Being an exporter has a similar effect except the advantages of greater size and liquidity diminish but cost influences increase.

In Table 4 we allow for firm size and for interaction of size with the crisis. Evidence in Berman et al. (2012) shows small exporters behave differently to large exporters. This could explain why we found differences between sensitivity of exporters and non-exporters to balance sheet variables in Table 3, but we did not explicitly test differences due to firm size. In Table 4 we report results from sub-samples of our data comprising small and large firms (columns 1 and 2) separated at the median of the distribution of real assets for all firms in our sample. ${ }^{19}$ We then allow for interactions between small and large firms and the crisis dummy (columns 3 and 4). Finally, to avoid the possibility that our results could be affected by firms that transit from small to large within our sample period, we re-estimate the model using interactions for small and large firms and the crisis dummy in the full sample (column 5), which also ensures we do not drop any firms with too few observations because they were observed as large or small for short durations.

The sales growth of small firms is lower than the sales growth of larger firms other things equal evidenced by a larger negative and significant constant for small firms. We find that small firms have larger estimated coefficients associated with total assets (size); liquidity (current asset ratio) has a positive influence on sales growth for small and large firms, but again the magnitude of

\footnotetext{
"Separation using the 33rd and 66th percentiles leaves our results unchanged.
} 
the coefficient is larger for small firms compared to large firms. As with the extensive margin, we find that these are the major determinants of exporting at the intensive margin.

The cost ratio which reflects the extent to which the firms can raise price above marginal cost has a smaller negative sign for small firms. Small firms have less market power than large firms, when their costs fall they benefit less than large firms from a reduction in their operating costs. Similarly, large firms benefit more from higher long-term loans ratios than small firms.

Results in columns 3-5, allowing interactions with the crisis dummy indicates that advantages due to size are magnified in a crisis, and the effects are larger for large firms. The crisis reduces the influence of other variables. When we consider the effect of being large in column 5, large firms

benefit more from higher long-term debt ratios, and less from greater short-term debt ratios and liquidity; however, being large, any further increase in size makes little difference to the export intensity. A large firm in the crisis gains most from raising the short-term loans ratio. Larger firms may have tested the market when their products were competitive, funding the expansion of sales with short-term debt. A test of significance for the interaction terms with dummies for large and crisis in column 5 is rejected ( $\mathrm{p}$-value $=0.0187$ ) which indicates that there was a significant

influence of the crisis on the sales growth at the intensive margin. We conclude that large firms have significantly different sales growth responses to the variables in our model compared to small firms. However, when we test the jointly zero restriction on the Large*Crisis interaction with the variables in our model we do not reject the null that the crisis experience is significantly different to non-crisis periods for large firms ( $\mathrm{p}$-value $=0.6255$ ).

Diagnostic statistics for Tables 3 and 4 do not reject the null hypotheses of no second-order serial correlation (m2) and valid instruments. The difference-in-Hansen statistics overwhelmingly support our choice of the system-GMM estimator over the alternative.

\section{Conclusions}

Our paper complements much of the literature on performance of exporters and non-exporters using firm-level panels (c.f.; Campa and Shaver, 2002; Harrison and McMillan, 2003; Berman and Héricourt 2010; Berman et al. 2012; Behrens et al. 2013; Manova et al. 2014), adding to our understanding of the effects of financial health on the extensive and intensive margin of exporters versus non-exporters by looking at the impact of the Brazilian crisis of 1999. Using a unified theoretical framework based on a two-sector extension of Holmström and Tirole (1997) model, we explore predictors that firms will engage in global markets and export more intensively. Our results based on a detailed firm-level panel of data for the entire population of exporting Brazilian firms from 1996-2006, show that the decision to export at the extensive margin is driven by size, liquidity, and the competitive effects of the crisis, supporting other evidence from developing countries 
reported Berman and Héricourt (2010) and Manova et al. (2014). When we examine the intensive margin through growth of sales, we find higher exposure to short-term loans reduces sales growth, reflecting the exposure firms face to rollover risk, but this can be offset to a degree by higher liquidity and total assets. There is also a clear competitiveness channel since our results show exporters fare less badly than non-exporters after the crisis and see a greater improvement after 2003. The findings confirm the mechanisms described in our model using available exporter status information from SECEX, but it would be informative to extend the empirical specification of the model using more disaggregated data where the destination of exports and product level data were available.

The main policy implication of our results is that larger firms and firms with greater liquidity are more insulated from shocks related to an exchange rate crisis. Financial health supports exports and sales growth, since severe economic shocks are less disruptive for these firms. The focus of policymakers seeking to ensure steady growth should be on the promotion of financial development, which is likely to enable firms to hold liquid assets and gain access to external finance, in order to be able to ride out shocks.

\section{Acknowledgements}

We thank the editor, Francis Teal, two anonymous referees, Mike Bleaney, John Driffill, Sourafel Girma, Alessandra Guariglia, Richard Kneller, Serafeim Tsoukas and seminar participants at the University of Nottingham at Ningbo, China and the Research Workshop on Finance and Development at Limassol, Cyprus for comments on this paper.

\section{Funding}

Leverhulme Trust (F114/BF) to SB; Hong Kong Institute of Monetary Research to PM. 


\section{References}

Allen, F. and D. Gale (2004) Competition and Financial Stability, Journal of Money, Credit, and Banking, 36, 453-480.

Akarım, Y. D. (2013) The Impact of Financial Factors on Export Decisions: The Evidence From Turkey, Economic Modelling, 35, 305-308.

Arellano, M. and S. Bond (1991) Some Tests of Specification for Panel Data: Monte Carlo Evidence and an Application to Employment Equations, Review of Economic Studies, 58, 277297.

Arellano, M. and O. Bover (1995) Another Look at the Instrumental Variable Estimation of ErrorComponents Models, Journal of Econometrics, 68, 29-51.

Aw, B.-Y. and A. Hwang (1995) Productivity and the Export Market: A Firm Level Analysis, Journal of Development Economics 47, 313-332.

Aw, B.-Y., S. Chung and M. Roberts (2000) Productivity and Turnover in the Export Market: Micro Evidence from Taiwan and South Korea, World Bank Economic Review 14, 65-90. Beck, T., A. Demirguc-Kunt and P. Honohan (2009) Access to Financial Services: Measurement, Impact and Policies,. World Bank Research Observer, 24, 119-145.

Behrens K, G. Corcos, G. Mion (2013) Trade Crisis? What Trade Crisis? Review of Economics and Statistics, 95, 702-709.

Berman N. and J. Héricourt (2010) Financial Factors and the Margins of Trade: Evidence from Cross-Country Firm-Level Data. Journal of Development Economics 93, 206-217.

Berman, N., P. Martin and T. Mayer (2012) How Do Different Exporters React to Exchange Rate Changes?, Quarterly Journal of Economics, 127, 437-492.

Bernard, A., J. Eaton, J. Jensen, and S. Kortum (2003) Plants and Productivity in International Trade, American Economic Review 93, 1268-1290.

Bernard, A. and B. Jensen (2004) Why Do Some Firms Export? Review of Economics and Statistics $86,561-569$.

Besedeš, T. and T.J. Prusa (2011) The Role of Extensive and Intensive Margins and Export Growth. Journal of Development Economics, 96, 371-379.

Besedeš, T., B-C. Kim and V. Lugovskyy (2014) Export Growth and Credit Constraints, European Economic Review, 70, 350-70.

Bigsten, A., P. Collier. S. Dercon, M. Fafchamps, B. Gauthier, J.W. Gunning, J. Haraburema, A. Oduro, R. Oostendorp, C. Pattillo, M. Söderbom, F. Teal and A. Zeufack (2004) Do African Manufacturing Firms Learn from Exporting? Journal of Development Studies, 40, 115-141.

Blalock, G., P. Gertler and D. Levine (2008) Financial Constraints on Investment in an Emerging Market Crisis, Journal of Monetary Economics 55, 568-591. 
Blalock, G. and S. Roy (2007) A Firm-level Examination of the Exports Puzzle: Why East Asian Exports Didn't Increase After the 1997-1998 Financial Crisis, World Economy 30, 39-59. Blundell, R. and S. Bond (1998) Initial Conditions and Moment Restrictions in Dynamic Panel Data Models, Journal of Econometrics 87, 115-143.

Bond, S., J. Elston, J. Mairesse and B. Mulkay (2003) Financial Factors and Investment in Belgium, France, Germany and the United Kingdom: A Comparison Using Company Panel Data, Review of Economics and Statistics 85, 153-165.

Bond, S., A. Hoeffler, and J. Temple (2001) GMM Estimations of Empirical Growth Models, CEPR discussion paper no. 3048.London.

Caballero, R. and M. Hammour (1994). The Cleansing Effects of Recessions. American Economic Review 84, 1350-1368.

Campa, J-M. and J-M. Shaver (2002) Exporting and Capital Investment on the Strategic Behavior of Exporters. IESE Business School, University of Navarra, Discussion Paper No. 469, Navarra. Chor, D. and K. Manova (2012) Off the Cliff and Back? Credit Conditions and International Trade

During the Global Financial Crisis, Journal of International Economics 87, 117-133.

Collyns, C. and G.R. Kincaid (2003) Managing Financial Crises Recent Experience and Lessons for Latin America, IMF Occasional Paper No. 217, Washington D.C.

Eichengreen, B. and M. Bordo (2003) Crises Now and Then: What Lessons from the Last Era of Financial Globalization in Monetary History, Exchange Rates and Financial Markets (P Mizen Ed), Edward Elgar, Cheltenham.

Fazzari, S., G. Hubbard and B. Petersen (1988) Financing Constraints and Corporate Investment, Brookings Papers on Economic Policy 1, 141-195.

Fazzari, S., G. Hubbard, and B. Petersen (2000) Investment-Cash Flow Sensitivities Are Useful: A Comment on Kaplan and Zingales, Quarterly Journal of Economics 115, 695-705.

Fazzari, S., and B. Petersen (1993) Working Capital and Fixed Investment: New Evidence on Financing Constraints, The RAND Journal of Economics 24, 328-42.

Forlani, E. (2011) Liquidity Constraints and Firm's Export Activity, Universite Catholique de Louvain - CORE, working paper January 2011, Louvain.

Girma, S., D. Greenaway, and R. Kneller (2004) Does Exporting Increase Productivity? A Microeconometric Analysis of Matched Firms, Review of International Economics 12, 855-866. Goldfajn, I. (2000) Public Debt Indexation and Denomination: The Case of Brazil, International Journal of Finance \& Economics,. 5, 43-56.

Goldstein, M. (2003) Debt Sustainability, Brazil, and the IMF. Institute for International Economics Working Paper No. 03-1, Washington D.C. 
Gopinath, G. and B. Neiman (2011) Trade Adjustment and Productivity in Large Crises, NBER Working Paper No. 16958, Boston.

Greenaway, D. and R. Kneller (2004) Exporting and Productivity in the United Kingdom, Oxford Review of Economic Policy, 20, 358-371.

Greenaway, D., A. Guariglia, and R. Kneller (2007) Financial Factors and Exporting Decisions. Journal of International Economics 73, 377-95.

Harrison, A. and M. McMillan (2003) Does Direct Foreign Investment Affect Domestic Firms Credit Constraints? Journal of International Economics 61, 73-100.

Helpman, E., M. Melitz, and S. Yeaple (2004) Export Versus FDI With Heterogeneous Firms, American Economic Review 94, 300-316.

Holmström, B. and J. Tirole (1997) Financial Intermediation, Loanable Funds, and the Real Sector, Quarterly Journal of Economics 112, 663-692.

Manova, K. (2013) Credit Constraints, Heterogeneous Firms, and International Trade, Review of Economic Studies, 80, 711-744.

Manova, K., S.-J. Wei and Z. Zhang (2014) Firm Exports and Multinational Activity under Credit Constraints, mimeo, Stanford University, Paolo Alto, California.

Melitz, M. (2003) The Impact of Trade on Intra-Industry Reallocations and Aggregate Industry Productivity, Econometrica 71, 1695-1725.

Mello, A.S. and J.E. Parsons (1992) Measuring Agency Cost of Debt, Journal of Finance 47, 18871904.

Myers, S. (1977) Determinants of Corporate Borrowing, Journal of Financial Economics 5, 146176.

Mulkay, B, and J. Mairesse (2013) The R\&D Tax Credit in France: Assessment and Ex Ante Evaluation of the 2008 Reform, Oxford Economic Papers, 65, 746-766.

Muûls, M. (2012) Exporters, Importers and Credit Constraints, CEP Discussion Papers dp1169, London School of Economics, London.

Rankin, N., M. Söderbom, and F. Teal (2006) Exporting from Manufacturing Firms in Sub-Saharan Africa. Journal of African Economies, 15, 671-687.

Roberts, M. and J. Tybout (1997) The Decision to Export in Colombia: An Empirical Model of Entry with Sunk Costs, American Economic Review 87, 545-564.

Roodman, D. (2009). How to do xtabond2: An Introduction to Difference and System GMM in Stata. Stata Journal, 9, 86-136.

Tybout, J. (2003) Plant- and Firm-Level Evidence on "New" Trade Theories, in E. Choi and J. Harrigan (eds.) Handbook of International Trade, Blackwell, Oxford. 
Table A1: List of sectors

\begin{tabular}{|c|c|c|c|}
\hline Sector & Freq. & Percent & Cum. \\
\hline Agriculture & 946 & 8.95 & 8.95 \\
\hline Appliances & 173 & 1.64 & 10.58 \\
\hline Beverages and Tobacco & 349 & 3.3 & 13.88 \\
\hline Chemical and Petrochemical & 636 & 6.02 & 19.9 \\
\hline Cleaning and Hygiene & 120 & 1.13 & 21.03 \\
\hline Construction & 555 & 5.25 & 26.28 \\
\hline Electric Equipment & 179 & 1.69 & 27.98 \\
\hline Electronics Materials & 150 & 1.42 & 29.4 \\
\hline Food & 1,102 & 10.42 & 39.82 \\
\hline Leather and Shoes & 257 & 2.43 & 42.25 \\
\hline Livestock & 420 & 3.97 & 46.22 \\
\hline Mechanics & 287 & 2.71 & 48.94 \\
\hline Metallurgy & 938 & 8.87 & 57.81 \\
\hline Mining & 208 & 1.97 & 59.77 \\
\hline Motor Vehicles and Parts & 624 & 5.9 & 65.68 \\
\hline Non-Metallic Mineral & 430 & 4.07 & 69.74 \\
\hline Office Supplies & 34 & 0.32 & 70.07 \\
\hline Petroleum and Gas & 144 & 1.36 & 71.43 \\
\hline Pharmaceutics & 173 & 1.64 & 73.06 \\
\hline Plastic and Rubber & 544 & 5.15 & 78.21 \\
\hline Pulp and Paper & 330 & 3.12 & 81.33 \\
\hline Sugarcane / Sugar / Alcohol & 573 & 5.42 & 86.75 \\
\hline Textile & 959 & 9.07 & 95.82 \\
\hline Various Fabrications & 39 & 0.37 & 96.19 \\
\hline Wood and Furniture & 403 & 3.81 & 100 \\
\hline
\end{tabular}

Total 10,573 100

Note: Only observations that present no missing values for any of the following variables included: Export Status, Total Assets, Short-Run Loans Ratio, Long-Run Loans Ratio, Cost Ratio, Current Assets Ratio, Current Ratio, and Effective Exchange Rate. More observations may be lost when lags are used in the estimations. 
Figure 1: The Incentive to Export and the Effective Exchange Rate

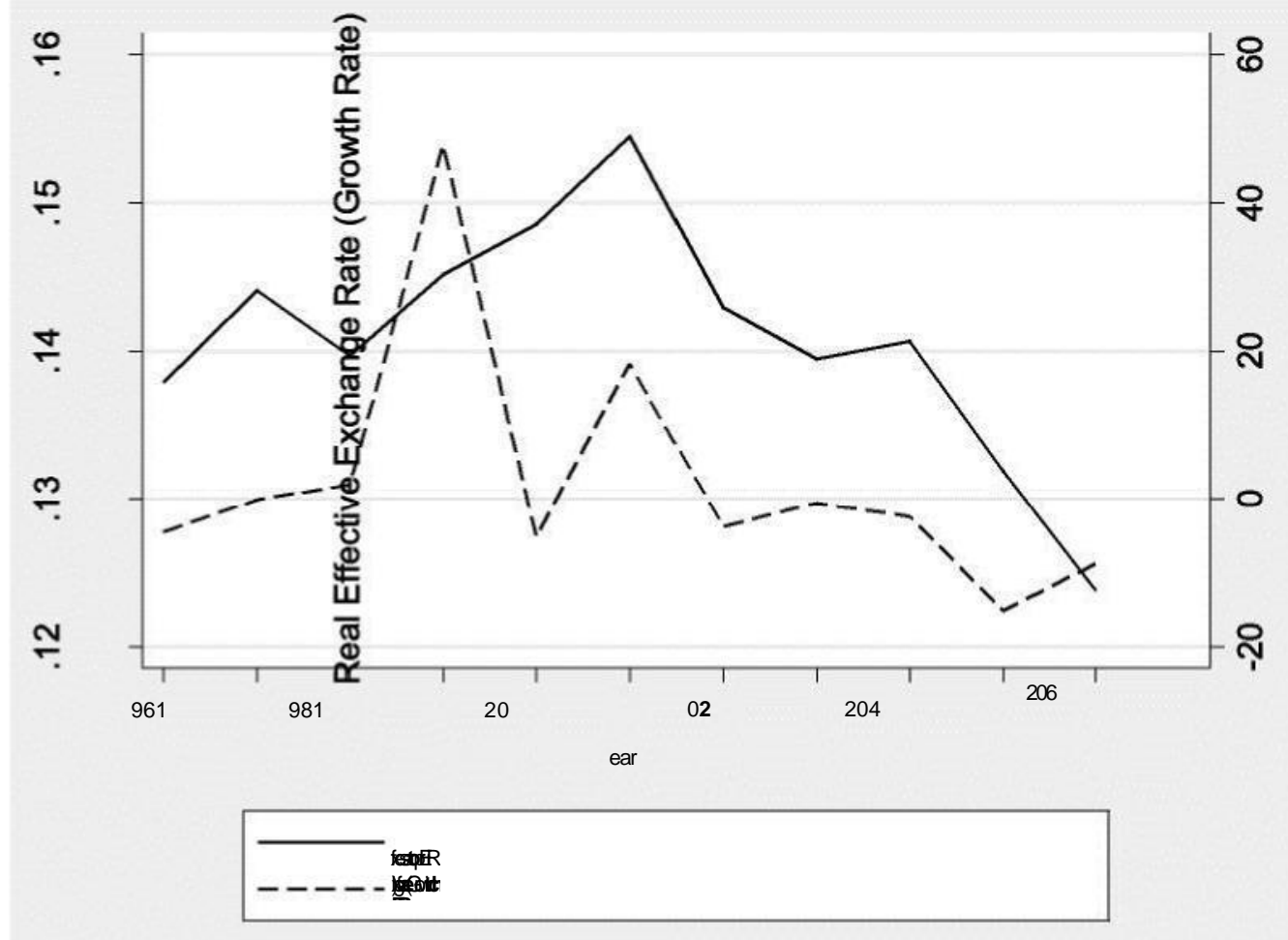

Sources: Real Effective Exchange Rate: IPEA (Research Institute of Applied Economics, www.ipeadata.gov.br). Number of Exporters: SECEX (Brazilian Secretary of International Trade, http://www.desenvolvimento.gov.br). Number of firms: IBGE (Brazilian Institute of Economy and Geography, www.ibge.gov.br). 
Figure 2: The Aggregate Export to GDP Ratio

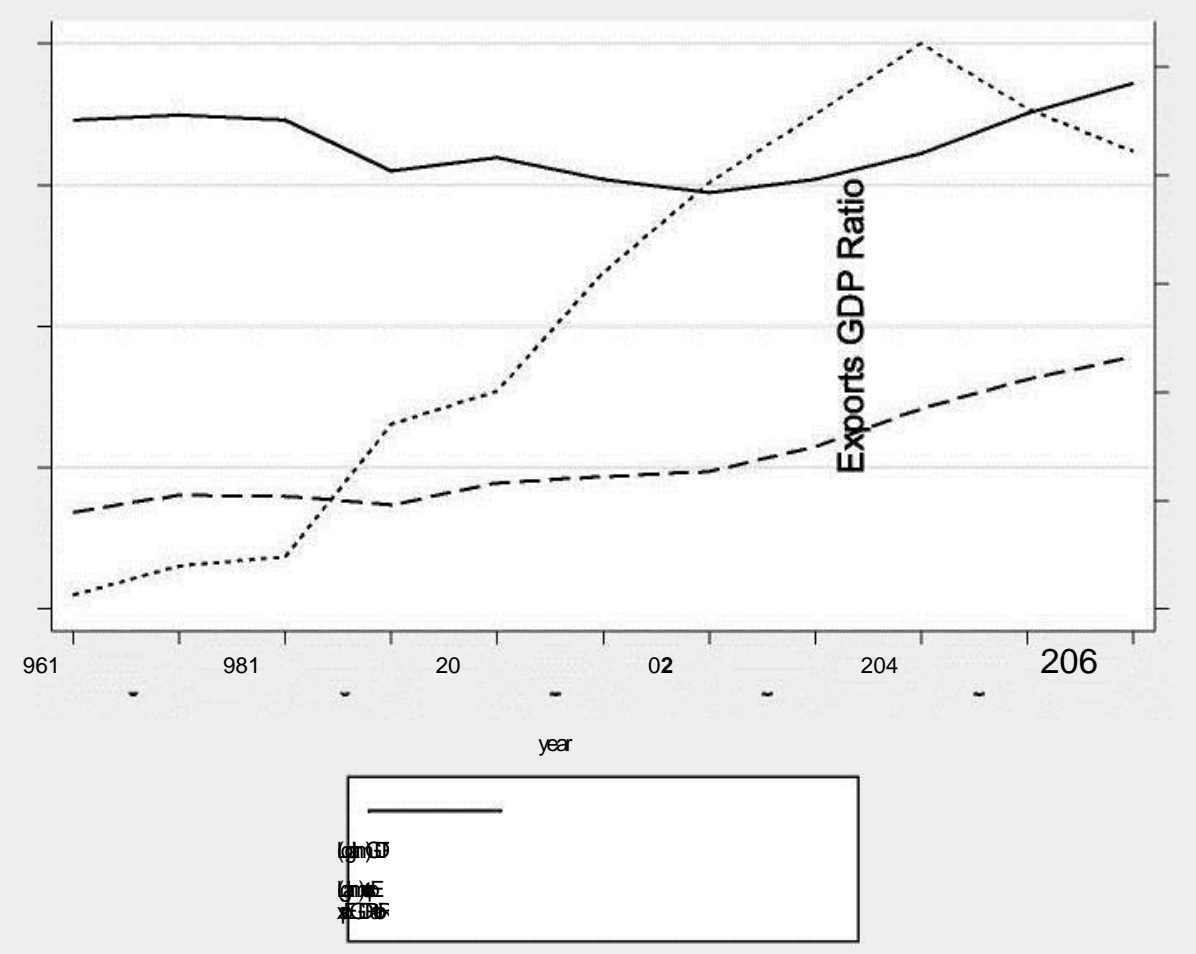

Source: World Bank. 
Table 1 - Descriptive Statistics Part 1

\begin{tabular}{lccccc}
\hline Variable & $\mathrm{N}$ & Median & $\mathrm{SD}$ & Min & Max \\
\hline Growth of Sales & 7587 & 0.03 & 0.55 & -7.01 & 8.34 \\
Export Status & 10573 & 0 & 0.5 & 0 & 1 \\
Total Assets* & 10573 & 18.5 & 52.1 & 0.298 & 1150 \\
Short-Run Loans Ratio & 10573 & 0.07 & 0.2 & 0 & 10.56 \\
Long-Run Loans Ratio & 10573 & 0.06 & 0.18 & 0 & 3.02 \\
Cost Ratio & 10573 & 0.77 & 146.93 & 0 & 14869.17 \\
Current Assets Ratio & 10573 & 0.42 & 0.21 & 0 & 0.98 \\
Current Ratio & 10573 & 1.4 & 2.75 & 0.01 & 100.55 \\
Real Effective Exchange & 10573 & -2.36 & 16.19 & -15.13 & 47.8 \\
Rate (Growth Rate, \%) & & &
\end{tabular}

Note: Only observations that present no missing values for any of the following variables included: Export Status, Total Assets, Short-Run Loans Ratio, Long-Run Loans Ratio, Cost Ratio, Current Assets Ratio, Current Ratio, and Effective Exchange Rate. More observations may be lost when lags are used in the estimations. * Units in millions of current dollars. 
Table 1 - Descriptive Statistics Part 2

\begin{tabular}{|c|c|c|c|c|c|}
\hline Variable & $\mathrm{N}$ & Median & SD & Min & Max \\
\hline \multicolumn{6}{|l|}{ Continuing exporters } \\
\hline Growth of Sales & 2060 & 0.02 & 0.39 & -2.09 & 7.18 \\
\hline Total Assets* & 2060 & 23.6 & 49.9 & 0.741 & 555 \\
\hline Short-Run Loans Ratio & 2060 & 0.09 & 0.22 & 0.00 & 8.44 \\
\hline Long-Run Loans Ratio & 2060 & 0.07 & 0.14 & 0 & 2.76 \\
\hline Cost Ratio & 2060 & 0.75 & 11.35 & 0.22 & 484.38 \\
\hline Current Assets Ratio & 2060 & 0.46 & 0.18 & 0.03 & 0.92 \\
\hline Current Ratio & 2060 & 1.4 & 1.48 & 0.05 & 40.37 \\
\hline \multicolumn{6}{|l|}{ Starters } \\
\hline Growth of Sales & 159 & 0.07 & 0.53 & -0.87 & 3.64 \\
\hline Total Assets* & 159 & 21.8 & 37.4 & 1.62 & 199 \\
\hline Short-Run Loans Ratio & 159 & 0.09 & 0.19 & 0 & 1.92 \\
\hline Long-Run Debt Ratio & 159 & 0.06 & 0.22 & 0 & 2.4 \\
\hline Cost Ratio & 159 & 0.79 & 4.25 & 0.23 & 52.38 \\
\hline Current Assets Ratio & 159 & 0.45 & 0.18 & 0.05 & 0.86 \\
\hline Current Ratio & 159 & 1.42 & 2.11 & 0.11 & 20.28 \\
\hline \multicolumn{6}{|l|}{ Stoppers } \\
\hline Growth of Sales & 151 & -0.05 & 0.52 & -1.13 & 3.6 \\
\hline Total Assets* & 151 & 22.4 & 49.0 & 1.89 & 343 \\
\hline Short-Run Loans Ratio & 151 & 0.08 & 0.18 & 0 & 1.81 \\
\hline Long-Run Debt Ratio & 151 & 0.08 & 0.22 & 0 & 1.8 \\
\hline Cost Ratio & 151 & 0.78 & 2.72 & 0.44 & 30.19 \\
\hline Current Assets Ratio & 151 & 0.42 & 0.19 & 0.03 & 0.9 \\
\hline Current Ratio & 151 & 1.34 & 1.65 & 0.09 & 14.37 \\
\hline
\end{tabular}

Note: Only observations that present no missing values for any of the following variables included: Export Status, Total Assets, Short-Run Loans Ratio, Long-Run Loans Ratio, Cost Ratio, Current Assets Ratio, Current Ratio, and Effective Exchange Rate. More observations may be lost when lags are used in the estimations. * Units in millions of current dollars.

\section{F tests for equality of means across groups - pvalue}

$\begin{array}{lcc} & \begin{array}{c}\text { All three } \\ \text { categories }\end{array} & \begin{array}{l}\text { Starters } \\ \text { and Cont. } \\ \text { Exps }\end{array} \\ \text { Growth of Sales } & 0.0041 & 0.0031 \\ \text { Total Assets } & 0.2167 & 0.0889 \\ \text { Short-Run Loans Ratio } & 0.9815 & 0.8489 \\ \text { Long-Run Debt Ratio } & 0.1061 & 0.3203 \\ \text { Cost Ratio } & 0.9934 & 0.9697 \\ \text { Current Assets Ratio } & 0.0209 & 0.5517 \\ \text { Current Ratio } & 0.3593 & 0.1670\end{array}$


Table 1- Descriptive Statistics Part 3

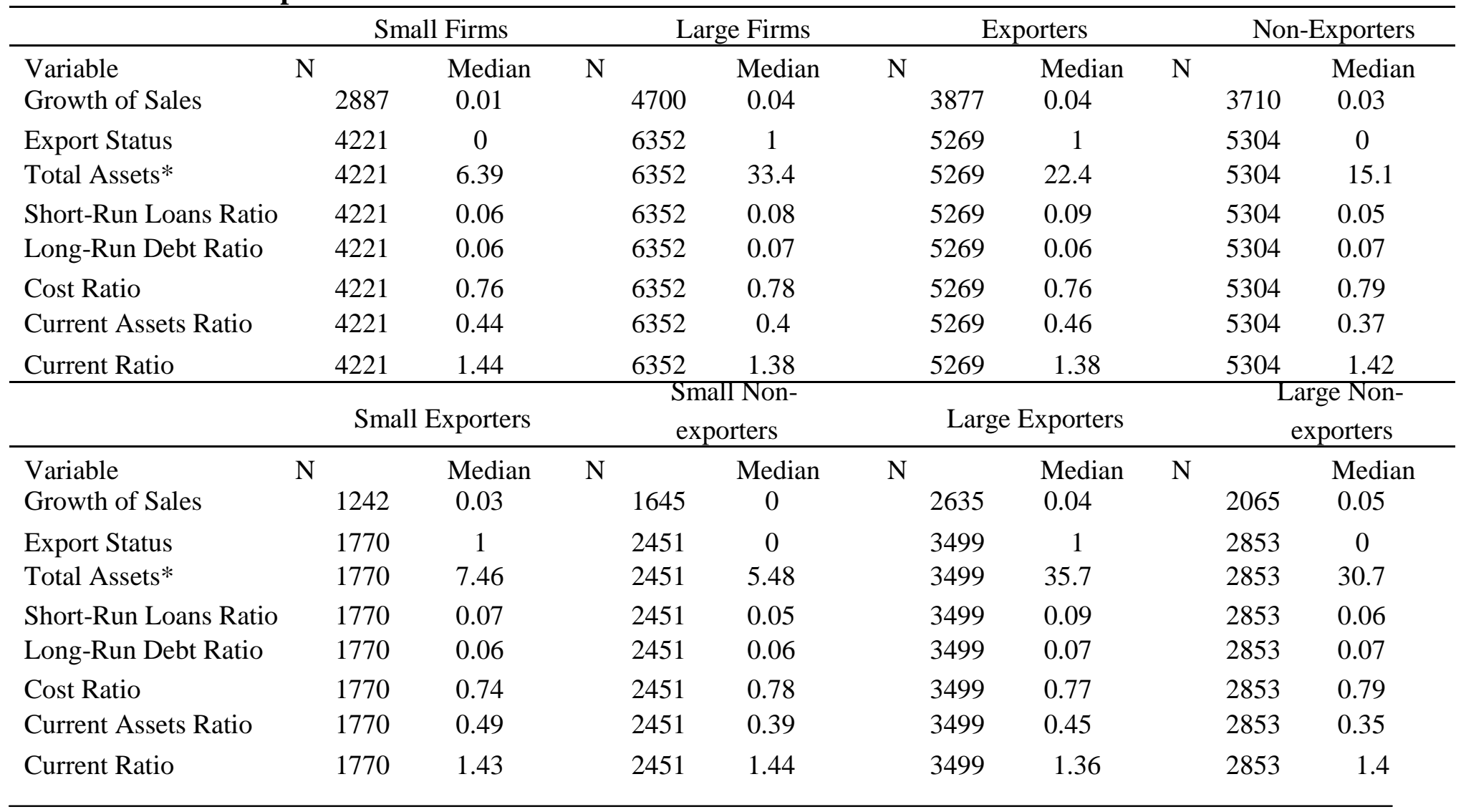

Note: Firms are classified as large or small based on the median of total assets by industry and year. Only observations that present no missing values for any of the following variables included: Export Status, Total Assets, Short-Run Loans Ratio, Long-Run Loans Ratio, Cost Ratio, Current Assets Ratio, Current Ratio, and Effective Exchange Rate. More observations may be lost when lags are used in the estimations. * Units in millions of current dollars. 
Table 2 Probit Model of Exporting at the Extensive Margin

\begin{tabular}{|c|c|c|c|c|c|}
\hline & $\begin{array}{c}(1) \\
\text { Pooled } \\
\text { Probit }\end{array}$ & $\begin{array}{c}(2) \\
\text { Random- } \\
\text { effects } \\
\text { Probit }\end{array}$ & $\begin{array}{c}\text { (3) } \\
\text { Fixed- } \\
\text { effects }\end{array}$ & $\begin{array}{c}(4) \\
\text { Dynamic } \\
\text { Pooled } \\
\text { Probit }\end{array}$ & $\begin{array}{c}(5) \\
\text { Dynamic } \\
\text { fixed- } \\
\text { effects }\end{array}$ \\
\hline $\begin{array}{l}\text { Change in Real Effective Exchange } \\
\text { Rate }\end{array}$ & 0.001 & $0.015^{*}$ & 0.002 & $0.006 * * *$ & $0.002 *$ \\
\hline & $(0.331)$ & $(0.069)$ & $(0.101)$ & $(0.006)$ & $(0.052)$ \\
\hline Dummy: Crisis & $\begin{array}{l}-0.027 \\
(0.721)\end{array}$ & $\begin{array}{l}-0.635 \\
(0.127)\end{array}$ & $\begin{array}{l}-0.075 \\
(0.151)\end{array}$ & $\begin{array}{c}-0.212 * * \\
(0.048)\end{array}$ & $\begin{array}{l}-0.086^{*} \\
(0.087)\end{array}$ \\
\hline Dummy: Year 2000 & $\begin{array}{c}0.011 \\
(0.623)\end{array}$ & $\begin{array}{c}0.048 \\
(0.658)\end{array}$ & $\begin{array}{c}0.004 \\
(0.764)\end{array}$ & $\begin{array}{c}0.045 \\
(0.152)\end{array}$ & $\begin{array}{c}0.007 \\
(0.590)\end{array}$ \\
\hline Dummy: Year 2001 & $\begin{array}{c}0.053 \\
(0.176)\end{array}$ & $\begin{array}{c}0.175 \\
(0.382)\end{array}$ & $\begin{array}{c}0.033 \\
(0.205)\end{array}$ & $\begin{array}{l}-0.012 \\
(0.825)\end{array}$ & $\begin{array}{c}0.018 \\
(0.460)\end{array}$ \\
\hline Dummy: Year 2002 & $\begin{array}{c}0.063 * * * \\
(0.002)\end{array}$ & $\begin{array}{l}0.320 * * * \\
(0.001)\end{array}$ & $\begin{array}{c}0.045 * * * \\
(0.001)\end{array}$ & $\begin{array}{l}-0.012 \\
(0.658)\end{array}$ & $\begin{array}{l}0.027 * * \\
(0.035)\end{array}$ \\
\hline Dummy: Year 2003 & $\begin{array}{c}0.120 * * * \\
(0.000)\end{array}$ & $\begin{array}{c}0.707 * * * \\
(0.000)\end{array}$ & $\begin{array}{c}0.104 * * * \\
(0.000)\end{array}$ & $\begin{array}{c}0.093 * * * \\
(0.010)\end{array}$ & $\begin{array}{c}0.082 * * * \\
(0.000)\end{array}$ \\
\hline GDP Growth Rate & $\begin{array}{c}0.024 * * * \\
(0.000)\end{array}$ & $\begin{array}{c}0.137 * * * \\
(0.000)\end{array}$ & $\begin{array}{c}0.019 * * * \\
(0.000)\end{array}$ & $\begin{array}{c}0.022 * * \\
(0.039)\end{array}$ & $\begin{array}{c}0.015 * * * \\
(0.001)\end{array}$ \\
\hline Commodity Prices Growth Rate & $\begin{array}{l}-0.002 \\
(0.119)\end{array}$ & $\begin{array}{l}-0.014 * \\
(0.073)\end{array}$ & $\begin{array}{c}-0.002 * * \\
(0.036)\end{array}$ & $\begin{array}{c}0.000 \\
(0.869)\end{array}$ & $\begin{array}{l}-0.001 \\
(0.123)\end{array}$ \\
\hline Total Assets (t-1) & $\begin{array}{c}0.099 * * * \\
(0.000)\end{array}$ & $\begin{array}{c}0.717 * * * \\
(0.000)\end{array}$ & $\begin{array}{c}0.111^{* * *} * \\
(0.000)\end{array}$ & $\begin{array}{c}0.043 * * * \\
(0.000)\end{array}$ & $\begin{array}{c}0.085 * * * \\
(0.000)\end{array}$ \\
\hline Short-Run Loans Ratio (t-1) & $\begin{array}{l}0.121 * \\
(0.075)\end{array}$ & $\begin{array}{c}0.129 \\
(0.611)\end{array}$ & $\begin{array}{l}-0.008 \\
(0.857)\end{array}$ & $\begin{array}{c}0.055 \\
(0.264)\end{array}$ & $\begin{array}{l}-0.022 \\
(0.608)\end{array}$ \\
\hline Long-Run Loans Ratio (t-1) & $\begin{array}{l}-0.037 \\
(0.641)\end{array}$ & $\begin{array}{c}0.009 \\
(0.972)\end{array}$ & $\begin{array}{l}-0.006 \\
(0.872)\end{array}$ & $\begin{array}{c}0.018 \\
(0.755)\end{array}$ & $\begin{array}{c}0.006 \\
(0.861)\end{array}$ \\
\hline Cost Ratio (t-1) & $\begin{array}{l}-0.000 \\
(0.149)\end{array}$ & $\begin{array}{l}-0.000 \\
(0.786)\end{array}$ & $\begin{array}{l}-0.000 \\
(0.636)\end{array}$ & $\begin{array}{l}-0.000 \\
(0.339)\end{array}$ & $\begin{array}{l}-0.000 \\
(0.578)\end{array}$ \\
\hline Current Assets Ratio (t-1) & $\begin{array}{c}0.372 * * * \\
(0.000)\end{array}$ & $\begin{array}{c}1.753 * * * \\
(0.000)\end{array}$ & $\begin{array}{c}0.169 * * * \\
(0.000)\end{array}$ & $\begin{array}{c}0.228 * * * \\
(0.000)\end{array}$ & $\begin{array}{c}0.129 * * * \\
(0.002)\end{array}$ \\
\hline Current Ratio (t-1) & $\begin{array}{c}-0.013 * * \\
(0.016)\end{array}$ & $\begin{array}{c}-0.058 * * * \\
(0.009)\end{array}$ & $\begin{array}{l}-0.001 \\
(0.613)\end{array}$ & $\begin{array}{c}-0.007 * \\
(0.074)\end{array}$ & $\begin{array}{l}-0.001 \\
(0.575)\end{array}$ \\
\hline Dummy for Exporter (t-1) & & & & $\begin{array}{c}0.766 * * * \\
(0.000)\end{array}$ & $\begin{array}{c}0.251 * * * \\
(0.000)\end{array}$ \\
\hline Constant & & & $\begin{array}{c}-1.473 * * * \\
(0.000)\end{array}$ & & $\begin{array}{c}-1.130 * * * \\
(0.000)\end{array}$ \\
\hline Number of observations & 7,690 & 7,736 & 7,736 & 7,690 & 7,736 \\
\hline R2 (see table notes) & 0.207 & & -0.355 & 0.568 & -0.268 \\
\hline Intra-class correlation (rho) & & $\begin{array}{c}.859 \\
(0.000)\end{array}$ & $\begin{array}{c}.735 \\
(0.000)\end{array}$ & & $\begin{array}{c}.644 \\
(0.000)\end{array}$ \\
\hline
\end{tabular}

Note: p-values in parentheses. All columns present probit results except for column 3, where the linear probability model is assumed. In Columns 1 and 4, pseudo $\mathrm{R}^{2}$ reported; robust variance estimation method is used (clustered by firm). In Columns 3 and 5 , overall $\mathrm{R}^{2}$ reported; the strong significance of the estimated intra-class correlations (Columns 2, 3 and 5) indicate strong association among observations of the same firm across years. In Columns 1, 2 and 4, Marginal effects (calculated at the average) reported. Coefficient estimates, not reported for the sake of space, present the same qualitative results and are available upon request. Dummies for industry effects and state effects are included in Columns 1, 2 and 4. * indicates significance at the $10 \%$ level. ** indicates significance at the 5\% level. *** indicates significance at the $1 \%$ level. (t-1) indicates the first lag of the respective variable. 


\begin{tabular}{|c|c|c|c|c|c|c|c|}
\hline & $\begin{array}{c}\text { (1) } \\
\text { Full } \\
\text { Sample }\end{array}$ & $\begin{array}{c}(2) \\
\text { Exporters }\end{array}$ & $\begin{array}{c}(3) \\
\text { Non- } \\
\text { Exporters }\end{array}$ & $\begin{array}{c}\text { (4) } \\
\text { Exporters } \\
\text { and crisis }\end{array}$ & $\begin{array}{c}(5) \\
\text { Non- } \\
\text { exporters, } \\
\text { and crisis }\end{array}$ & $\begin{array}{l}\quad(6) \\
\text { Exporters } \\
\text { and crisis }\end{array}$ & $\begin{array}{l}\text { (7) } \\
\text { Exporters, } \\
\text { crisis and } \\
\text { exporters* } \\
\text { crisis }\end{array}$ \\
\hline Growth of Sales-1 & $\begin{array}{c}-0.112 * * * \\
(0.000)\end{array}$ & $\begin{array}{c}-0.064 * * * \\
(0.000)\end{array}$ & $\begin{array}{c}-0.149 * * * \\
(0.000)\end{array}$ & $\begin{array}{c}-0.023^{* * * *} \\
(0.000)\end{array}$ & $\begin{array}{c}-0.112 * * * \\
(0.000)\end{array}$ & $\begin{array}{r}-0.079 * * * \\
(0.000)\end{array}$ & $\begin{array}{c}-0.074 * * * \\
(0.000)\end{array}$ \\
\hline Total Assets (TA) & $\begin{array}{c}0.161 * * * \\
(0.000)\end{array}$ & $\begin{array}{c}0.050^{* * * *} \\
(0.000)\end{array}$ & $\begin{array}{c}0.197 * * * \\
(0.000)\end{array}$ & $\begin{array}{r}0.031 * * * \\
(0.000)\end{array}$ & $\begin{array}{c}0.150^{* * * *} \\
(0.000)\end{array}$ & $\begin{array}{r}0.098^{* * *} \\
(0.000)\end{array}$ & $\begin{array}{l}0.095 * * * \\
(0.000)\end{array}$ \\
\hline Crisis* TA & & & & $\begin{array}{r}0.063 * * * \\
(0.000)\end{array}$ & $\begin{array}{c}0.080 * * * \\
(0.000)\end{array}$ & $\begin{array}{r}0.021 * * * \\
(0.000)\end{array}$ & $\begin{array}{l}0.008^{*} \\
(0.099)\end{array}$ \\
\hline Exporter* TA & & & & & & $\begin{array}{r}-0.046^{* * * *} \\
(0.000)\end{array}$ & $\begin{array}{c}-0.032 * * * \\
(0.000)\end{array}$ \\
\hline Exporter* Crisis*TA & & & & & & & $\begin{array}{l}0.004 * * * \\
(0.009)\end{array}$ \\
\hline $\begin{array}{l}\text { Short-Run Loans } \\
\text { Ratio (SLR) }\end{array}$ & 0.022 & $0.014 * *$ & $-0.119 * * *$ & $0.020 * * *$ & $-0.341 * * *$ & $-0.080 * * *$ & $-0.112 * * *$ \\
\hline & $(0.127)$ & $(0.033)$ & $(0.000)$ & $(0.001)$ & $(0.000)$ & $(0.000)$ & $(0.000)$ \\
\hline Crisis*SLR & & & & $\begin{array}{r}0.192 * * * \\
(0.000)\end{array}$ & $\begin{array}{l}-0.099 \\
(0.306)\end{array}$ & $\begin{array}{r}0.205^{* * * *} \\
(0.000)\end{array}$ & $\begin{array}{l}0.382 * * * \\
(0.000)\end{array}$ \\
\hline Exporter* SLR & & & & & & $\begin{array}{r}0.046 * * * \\
(0.001)\end{array}$ & $\begin{array}{l}0.100 \text { *** } \\
(0.000)\end{array}$ \\
\hline Exporter* Crisis*SLR & & & & & & & $\begin{array}{c}-0.274 * * * \\
(0.007)\end{array}$ \\
\hline Long-Run Loans Ratio & $0.137 * * *$ & $0.077 * * *$ & $0.128 * * *$ & $0.097 * * *$ & $0.079 * * *$ & $-0.014 *$ & $-0.018^{* * *}$ \\
\hline & $(0.000)$ & $(0.000)$ & $(0.000)$ & $(0.000)$ & $(0.000)$ & $(0.082)$ & (0.009) \\
\hline Crisis* LLR & & & & $\begin{array}{r}0.237 * * * \\
(0.000)\end{array}$ & $\begin{array}{c}-0.209 * * * \\
(0.000)\end{array}$ & $\begin{array}{r}-0.242 * * * \\
(0.000)\end{array}$ & $\begin{array}{c}-0.316 * * * \\
(0.000)\end{array}$ \\
\hline Exporter* LLR & & & & & & $\begin{array}{r}0.122 * * * \\
(0.000)\end{array}$ & $\begin{array}{l}0.125^{* * * *} \\
(0.000)\end{array}$ \\
\hline Exporter* Crisis* LLR & & & & & & & $\begin{array}{l}0.484 * * * \\
(0.000)\end{array}$ \\
\hline Cost Ratio (C) & $\begin{array}{c}-0.004 * * * \\
(0.000)\end{array}$ & $\begin{array}{c}-0.010^{* * * *} \\
(0.000)\end{array}$ & $\begin{array}{c}-0.004 * * * \\
(0.000)\end{array}$ & $\begin{array}{c}-0.019 * * * * \\
(0.000)\end{array}$ & $\begin{array}{c}-0.004 * * * \\
(0.000)\end{array}$ & $\begin{array}{r}-0.004 * * * \\
(0.000)\end{array}$ & $\begin{array}{l}-0.004 * * * \\
(0.000)\end{array}$ \\
\hline Crisis $* \mathrm{C}$ & & & & $\begin{array}{r}0.048 * * * \\
(0.000)\end{array}$ & $\begin{array}{c}0.033 * * * \\
(0.000)\end{array}$ & $\begin{array}{r}0.029 * * * \\
(0.000)\end{array}$ & $\begin{array}{l}0.030 * * * \\
(0.000)\end{array}$ \\
\hline Exporter*C & & & & & & $\begin{array}{r}-0.016^{* * * *} \\
(0.000)\end{array}$ & $\begin{array}{c}-0.016 * * * \\
(0.000)\end{array}$ \\
\hline Exporter* Crisis ${ }^{*} \mathrm{C}$ & & & & & & & $\begin{array}{l}-0.001 * \\
(0.100)\end{array}$ \\
\hline $\begin{array}{l}\text { Current Assets Ratio } \\
\text { (CA) }\end{array}$ & $1.131 * * *$ & $0.712 * * *$ & $1.126 * * *$ & $0.200 * * *$ & $0.605 * * *$ & $0.461 * * *$ & $0.394 * * *$ \\
\hline Crisis* CA & $(0.000)$ & $(0.000)$ & $(0.000)$ & $\begin{array}{c}(0.000) \\
-0.166^{* * *} \\
(0.001)\end{array}$ & $\begin{array}{l}(0.000) \\
-0.015 \\
(0.503)\end{array}$ & $\begin{array}{r}(0.000) \\
-0.072 * * * \\
(0.000)\end{array}$ & $\begin{array}{l}(0.000) \\
-0.008 \\
(0.724)\end{array}$ \\
\hline Exporter $* \mathrm{CA}$ & & & & & & $\begin{array}{r}-0.244 * * * \\
(0.000)\end{array}$ & $\begin{array}{c}-0.068 * * * \\
(0.000)\end{array}$ \\
\hline Exporter* Crisis*CA & & & & & & & $\begin{array}{c}-0.134 * * * \\
(0.001)\end{array}$ \\
\hline Current Ratio (CR) & $\begin{array}{c}-0.014 * * * \\
(0.000)\end{array}$ & $\begin{array}{c}-0.001 * * * \\
(0.007)\end{array}$ & $\begin{array}{c}-0.020 * * * \\
(0.000)\end{array}$ & $\begin{array}{r}0.004 * * * \\
(0.000)\end{array}$ & $\begin{array}{c}-0.014 * * * \\
(0.000)\end{array}$ & $\begin{array}{r}-0.007 * * * * \\
(0.000)\end{array}$ & $\begin{array}{c}-0.008 * * * \\
(0.000)\end{array}$ \\
\hline Crisis* CR & & & & $\begin{array}{r}0.019 * * * \\
(0.000)\end{array}$ & $\begin{array}{c}-0.006^{* * *} * \\
(0.001)\end{array}$ & $\begin{array}{r}-0.007 * * * \\
(0.000)\end{array}$ & $\begin{array}{c}-0.007 * * * \\
(0.001)\end{array}$ \\
\hline Exporter $* \mathrm{CR}$ & & & & & & $\begin{array}{r}0.004 * * * \\
(0.000)\end{array}$ & $\begin{array}{l}0.010 \text { *** } \\
(0.000)\end{array}$ \\
\hline Exporter* Crisis*CR & & & & & & & $\begin{array}{l}0.020 * * * \\
(0.000)\end{array}$ \\
\hline
\end{tabular}




\begin{tabular}{|c|c|c|c|c|c|c|c|}
\hline & $\begin{array}{c}(1) \\
\text { Full } \\
\text { Sample }\end{array}$ & $\begin{array}{c}(2) \\
\text { Exporters }\end{array}$ & $\begin{array}{c}(3) \\
\text { Non- } \\
\text { Exporters }\end{array}$ & $\begin{array}{l}\text { (4) } \\
\text { Exporters } \\
\text { and crisis }\end{array}$ & $\begin{array}{c}(5) \\
\text { Non- } \\
\text { exporters } \\
\text { and crisis }\end{array}$ & $\begin{array}{l}(6) \\
\text { Exporters } \\
\text { and crisis }\end{array}$ & $\begin{array}{c}(7) \\
\text { Exporters } \\
\text { crisis and } \\
\text { exporters } \\
* \text { crisis } \\
\end{array}$ \\
\hline $\begin{array}{l}\text { Dummy: Export } \\
\text { Status }\end{array}$ & $\begin{array}{c}-0.007 * * * \\
(0.000)\end{array}$ & & & & & $\begin{array}{c}0.863 * * * \\
(0.000)\end{array}$ & $\begin{array}{c}0.505 * * * \\
(0.000)\end{array}$ \\
\hline Dummy: Crisis & $\begin{array}{l}-0.027 \\
(0.104)\end{array}$ & $\begin{array}{c}-0.128 * * * \\
(0.000)\end{array}$ & $\begin{array}{c}0.131 * * * \\
(0.000)\end{array}$ & $\begin{array}{c}-1.202 * * * \\
(0.000)\end{array}$ & $\begin{array}{c}-1.093 * * * \\
(0.000)\end{array}$ & $\begin{array}{c}-0.276^{* * * *} \\
(0.000)\end{array}$ & $\begin{array}{l}-0.138^{*} \\
(0.074)\end{array}$ \\
\hline Dummy: Year 2000 & $\begin{array}{c}-0.037 * * * \\
(0.000)\end{array}$ & $\begin{array}{c}-0.064 * * * \\
(0.000)\end{array}$ & $\begin{array}{c}-0.037 * * * \\
(0.000)\end{array}$ & $\begin{array}{c}-0.056 * * * \\
(0.000)\end{array}$ & $\begin{array}{c}-0.053 * * * \\
(0.000)\end{array}$ & $\begin{array}{c}-0.058 * * * \\
(0.000)\end{array}$ & $\begin{array}{c}-0.053 * * * * \\
(0.000)\end{array}$ \\
\hline Dummy: Year 2001 & $\begin{array}{c}0.075^{* * * *} \\
(0.000)\end{array}$ & $\begin{array}{c}-0.009 * * \\
(0.047)\end{array}$ & $\begin{array}{c}0.159 * * * \\
(0.000)\end{array}$ & $\begin{array}{r}-0.013^{*} \\
(0.057)\end{array}$ & $\begin{array}{c}0.174 * * * \\
(0.000)\end{array}$ & $\begin{array}{c}0.083 * * * \\
(0.000)\end{array}$ & $\begin{array}{c}0.083 * * * \\
(0.000)\end{array}$ \\
\hline Dummy: Year 2002 & $\begin{array}{c}-0.210^{* * * *} \\
(0.000)\end{array}$ & $\begin{array}{c}-0.288 * * * \\
(0.000)\end{array}$ & $\begin{array}{l}-0.181^{* * * *} \\
(0.000)\end{array}$ & $\begin{array}{c}-0.292 * * * \\
(0.000)\end{array}$ & $\begin{array}{c}-0.196 * * * \\
(0.000)\end{array}$ & $\begin{array}{c}-0.249 * * * \\
(0.000)\end{array}$ & $\begin{array}{c}-0.245 * * * \\
(0.000)\end{array}$ \\
\hline Dummy: Year 2003 & $\begin{array}{c}0.385 * * * \\
(0.000)\end{array}$ & $\begin{array}{c}0.397 * * * \\
(0.000)\end{array}$ & $\begin{array}{l}0.350 * * * \\
(0.000)\end{array}$ & $\begin{array}{c}0.408 * * * \\
(0.000)\end{array}$ & $\begin{array}{c}0.368 * * * \\
(0.000)\end{array}$ & $\begin{array}{c}0.385^{* * * *} \\
(0.000)\end{array}$ & $\begin{array}{c}0.388^{* * * *} \\
(0.000)\end{array}$ \\
\hline $\begin{array}{l}\text { Change in Real } \\
\text { Effective Exchange } \\
\text { Rate }\end{array}$ & $-0.003 * * *$ & $-0.001 * * *$ & $-0.007 * * *$ & $-0.001 * * *$ & $-0.009 * * *$ & $-0.005 * * *$ & $-0.005^{* * *}$ \\
\hline GDP Growth Rate & $\begin{array}{c}(0.000) \\
0.052 * * * \\
(0.000)\end{array}$ & $\begin{array}{c}(0.000) \\
0.061 * * * \\
(0.000)\end{array}$ & $\begin{array}{c}(0.000) \\
0.040^{* * * *} \\
(0.000)\end{array}$ & $\begin{array}{c}(0.000) \\
0.058^{* * * *} \\
(0.000)\end{array}$ & $\begin{array}{c}(0.000) \\
0.039 * * * \\
(0.000)\end{array}$ & $\begin{array}{c}(0.000) \\
0.050 * * * \\
(0.000)\end{array}$ & $\begin{array}{c}(0.000) \\
0.050^{* * * *} \\
(0.000)\end{array}$ \\
\hline $\begin{array}{l}\text { Commodity Prices } \\
\text { Growth Rate }\end{array}$ & $\begin{array}{c}-0.006^{* * *} \\
(0.000)\end{array}$ & $\begin{array}{c}-0.005^{* * *} \\
(0.000)\end{array}$ & $\begin{array}{c}-0.005^{* * *} \\
(0.000)\end{array}$ & $\begin{array}{c}-0.003 * * * \\
(0.000)\end{array}$ & $\begin{array}{c}-0.003 * * * \\
(0.000)\end{array}$ & $\begin{array}{c}-0.003 * * * \\
(0.000)\end{array}$ & $\begin{array}{c}-0.003^{* * *} \\
(0.000)\end{array}$ \\
\hline Constant & $\begin{array}{c}-3.197 * * * \\
(0.000)\end{array}$ & $\begin{array}{c}-0.812 * * * \\
(0.000)\end{array}$ & $\begin{array}{c}-3.889 * * * \\
(0.000)\end{array}$ & $\begin{array}{c}-0.667 * * * \\
(0.000)\end{array}$ & $\begin{array}{c}-3.067 * * * \\
(0.000)\end{array}$ & $\begin{array}{c}-2.080^{* * * *} \\
(0.000)\end{array}$ & $\begin{array}{c}-1.966 * * * \\
(0.000)\end{array}$ \\
\hline $\begin{array}{l}\text { Number of } \\
\text { observations }\end{array}$ & 5,549 & 2,896 & 2,653 & 2,896 & 2,653 & 5,549 & 5,549 \\
\hline $\begin{array}{l}\text { Hansen Statistics (p- } \\
\text { value) }\end{array}$ & 0.005 & 0.224 & 0.327 & 0.155 & 0.213 & 0.187 & 0.219 \\
\hline $\begin{array}{l}\text { Difference-in-Hansen } \\
\text { test } \\
\text { (p-value) }\end{array}$ & 0.336 & 0.121 & 0.447 & 0.041 & 0.364 & 0.060 & 0.141 \\
\hline m1 (p-value) & 0.000 & 0.000 & 0.000 & 0.000 & 0.000 & 0.000 & 0.000 \\
\hline m1 (p-value) & 0.776 & 0.014 & 0.518 & 0.016 & 0.840 & 0.832 & 0.756 \\
\hline $\begin{array}{l}\text { Number of } \\
\text { Instruments }\end{array}$ & 561 & 492 & 497 & 504 & 509 & 957 & 969 \\
\hline
\end{tabular}

Note: p-values in parentheses. All estimates use two-step, system GMM, with fixed effects for industries and states. Exporter is a dummy equal to 1 if firm i exports in year t. Crisis is a dummy equal to 1 if year is larger or equal to 1999. The Hansen statistic for valid overidentifying restrictions is distributed ${ }^{2}$ under the null of instrument validity. $m l(m 2)$ is a test for first- (second-) order serial correlation in the first-differenced residuals, asymptotically distributed as $\mathrm{N}(0,1)$ under the null of no serial correlation. Difference-in-Hansen Statistics test the validity of System GMM under the null of valid System GMM instruments. Dummies for industry, year and state are exogenous and are included in the "IV-style" (Roodman, 2009) form. Endogenous variables are instrumented in the "GMM-style" (Roodman, 2009) using lags $\geq 2$ in the transformed equation and lags $\geq 1$ in the level equation. * indicates significance at the $10 \%$ level. ** indicates significance at the $5 \%$ level. $* * *$ indicates significance at the $1 \%$ level. 
Table 4: GMM Regressions of the Intensive Margin (Small v. Large Firms)

\begin{tabular}{|c|c|c|c|c|c|}
\hline & $\begin{array}{l}(1) \\
\text { Small } \\
\text { Firms }\end{array}$ & $\begin{array}{c}(2) \\
\text { Large Firms }\end{array}$ & $\begin{array}{c}\text { (3) } \\
\text { Small firms, } \\
\text { and crisis }\end{array}$ & $\begin{array}{c}\text { (4) } \\
\text { Large firms } \\
\text { and crisis }\end{array}$ & $\begin{array}{l}\quad(5) \\
\text { All firms, } \\
\text { crisis and } \\
\text { size }\end{array}$ \\
\hline Growth of Sales-1 & $\begin{array}{c}-0.114 * * * \\
(0.000)\end{array}$ & $\begin{array}{c}-0.117 * * * \\
(0.000)\end{array}$ & $\begin{array}{c}-0.070 * * * \\
(0.000)\end{array}$ & $\begin{array}{c}-0.100 * * * \\
(0.000)\end{array}$ & $\begin{array}{c}-0.068 * * * \\
(0.000)\end{array}$ \\
\hline Total Assets (TA) & $\begin{array}{c}0.205^{* * * *} \\
(0.000)\end{array}$ & $\begin{array}{c}0.072 * * * \\
(0.000)\end{array}$ & $\begin{array}{c}0.214 * * * \\
(0.000)\end{array}$ & $\begin{array}{c}0.077 * * * \\
(0.000)\end{array}$ & $\begin{array}{c}0.073 * * * \\
(0.000)\end{array}$ \\
\hline Crisis* TA & & & $\begin{array}{c}0.086 * * * \\
(0.000)\end{array}$ & $\begin{array}{c}0.136 * * * \\
(0.000)\end{array}$ & $\begin{array}{c}-0.064 * * * \\
(0.000)\end{array}$ \\
\hline Large* TA & & & & & $\begin{array}{c}-0.001 * * * \\
(0.000)\end{array}$ \\
\hline Large*Crisis*TA & & & & & $\begin{array}{c}0.008 * * * \\
(0.000)\end{array}$ \\
\hline Short-Run Loans Ratio & $\begin{array}{c}0.014 * * * \\
(0.000)\end{array}$ & $\begin{array}{c}-0.135^{* * *} \\
(0.000)\end{array}$ & $\begin{array}{c}-0.002 \\
(0.487)\end{array}$ & $\begin{array}{c}-0.229 * * * \\
(0.000)\end{array}$ & $\begin{array}{c}0.016 * * * \\
(0.003)\end{array}$ \\
\hline Crisis*SLR & & & $\begin{array}{c}0.002 \\
(0.985)\end{array}$ & $\begin{array}{c}0.143 * * \\
(0.036)\end{array}$ & $\begin{array}{c}-0.001 \\
(0.957)\end{array}$ \\
\hline Large* SLR & & & & & $\begin{array}{c}-0.302 * * * \\
(0.000)\end{array}$ \\
\hline Large*Crisis*SLR & & & & & $\begin{array}{c}0.703^{* * *} * \\
(0.000)\end{array}$ \\
\hline Long-Run Loans Ratio & $\begin{array}{c}0.139 * * * * \\
(0.000)\end{array}$ & $\begin{array}{c}0.268 * * * \\
(0.000)\end{array}$ & $\begin{array}{c}0.090 * * * \\
(0.000)\end{array}$ & $\begin{array}{c}0.181 * * * \\
(0.000)\end{array}$ & $\begin{array}{c}-0.033 * * * \\
(0.000)\end{array}$ \\
\hline Crisis* LLR & & & $\begin{array}{c}-0.194 * * * \\
(0.000)\end{array}$ & $\begin{array}{c}0.031 \\
(0.625)\end{array}$ & $\begin{array}{c}-0.257 * * * \\
(0.000)\end{array}$ \\
\hline Large* LLR & & & & & $\begin{array}{c}0.252 * * * \\
(0.000)\end{array}$ \\
\hline Large*Crisis* LLR & & & & & $\begin{array}{c}-0.128 * * \\
(0.032)\end{array}$ \\
\hline Cost Ratio (C) & $\begin{array}{c}-0.004 * * * \\
(0.000)\end{array}$ & $\begin{array}{c}-0.017 * * * \\
(0.000)\end{array}$ & $\begin{array}{c}-0.004 * * * \\
(0.000)\end{array}$ & $\begin{array}{c}-0.017 * * * \\
(0.000)\end{array}$ & $\begin{array}{c}-0.004 * * * \\
(0.000)\end{array}$ \\
\hline Crisis*C & & & $\begin{array}{c}0.035 * * * \\
(0.000)\end{array}$ & $\begin{array}{c}-0.016 * * * \\
(0.000)\end{array}$ & $\begin{array}{c}0.037 * * * \\
(0.000)\end{array}$ \\
\hline Large $* \mathrm{C}$ & & & & & $\begin{array}{c}-0.013 * * * \\
(0.000)\end{array}$ \\
\hline Large $*$ Crisis $* \mathrm{C}$ & & & & & $\begin{array}{c}-0.059 * * * \\
(0.000)\end{array}$ \\
\hline Current Assets Ratio (CA) & $\begin{array}{c}1.238 * * * \\
(0.000)\end{array}$ & $\begin{array}{c}0.980 * * * \\
(0.000)\end{array}$ & $\begin{array}{c}0.624 * * * \\
(0.000)\end{array}$ & $\begin{array}{c}0.374 * * * \\
(0.000)\end{array}$ & $\begin{array}{c}0.473 * * * \\
(0.000)\end{array}$ \\
\hline Crisis* CA & & & $\begin{array}{c}0.025 \\
(0.574)\end{array}$ & $\begin{array}{c}-0.154 * * * \\
(0.000)\end{array}$ & $\begin{array}{r}-0.093^{*} \\
(0.056)\end{array}$ \\
\hline Large*CA & & & & & $\begin{array}{c}-0.174 * * * \\
(0.000)\end{array}$ \\
\hline Large $*$ Crisis $* \mathrm{CA}$ & & & & & $\begin{array}{r}-0.078 \\
(0.152)\end{array}$ \\
\hline Current Ratio (CR) & $\begin{array}{c}-0.015^{* * *} \\
(0.000)\end{array}$ & $\begin{array}{c}-0.012 * * * \\
(0.000)\end{array}$ & $\begin{array}{c}-0.013 * * * \\
(0.000)\end{array}$ & $\begin{array}{c}-0.015 * * * \\
(0.000)\end{array}$ & $\begin{array}{c}-0.010 * * * \\
(0.000)\end{array}$ \\
\hline Crisis* CR & & & $\begin{array}{c}-0.002 * * \\
(0.039)\end{array}$ & $\begin{array}{c}0.010 * * * \\
(0.000)\end{array}$ & $\begin{array}{c}-0.002 * * \\
(0.047)\end{array}$ \\
\hline Large*CR & & & & & $\begin{array}{c}0.012 * * * \\
(0.000)\end{array}$ \\
\hline Large*Crisis*CR & & & & & $\begin{array}{c}-0.010 * * * \\
(0.000)\end{array}$ \\
\hline
\end{tabular}


Table 4: GMM Regressions of the Intensive Margin (Small v. Large Firms) (Continued)

(1)

S m a 11

Fir m s
(2)

Large Firms
(3)

Small firms, and crisis
(4)

Large firms and crisis
(5)

All firms, crisis and size

\begin{tabular}{|c|c|c|c|c|c|}
\hline Dummy: Export Status & $\begin{array}{c}0.036 * * * \\
(0.000)\end{array}$ & $\begin{array}{l}-0.032 * * * \\
(0.000)\end{array}$ & $\begin{array}{c}0.088^{* * *} \\
(0.000)\end{array}$ & $\begin{array}{l}-0.053 * * * \\
(0.000)\end{array}$ & $\begin{array}{c}0.020 * * * \\
(0.000)\end{array}$ \\
\hline Dummy: Crisis & $\begin{array}{l}0.281 * * * \\
(0.000)\end{array}$ & $\begin{array}{c}-0.262 * * * \\
(0.000)\end{array}$ & $\begin{array}{l}-1.027 * * * \\
(0.000)\end{array}$ & $\begin{array}{l}-2.488 * * * \\
(0.000)\end{array}$ & $\begin{array}{c}1.061^{* * * *} \\
(0.000)\end{array}$ \\
\hline Dummy: Year 2000 & $\begin{array}{l}-0.054 * * * \\
(0.000)\end{array}$ & $\begin{array}{l}-0.055^{* * *} \\
(0.000)\end{array}$ & $\begin{array}{c}-0.043 * * * \\
(0.000)\end{array}$ & $\begin{array}{l}-0.065^{* * *} \\
(0.000)\end{array}$ & $\begin{array}{l}-0.050 * * * \\
(0.000)\end{array}$ \\
\hline Dummy: Year 2001 & $\begin{array}{c}0.186 * * * \\
(0.000)\end{array}$ & $\begin{array}{l}-0.050 * * * \\
(0.000)\end{array}$ & $\begin{array}{l}0.200 * * * \\
(0.000)\end{array}$ & $\begin{array}{l}-0.006 \\
(0.390)\end{array}$ & $\begin{array}{c}0.076^{* * * *} \\
(0.000)\end{array}$ \\
\hline Dummy: Year 2002 & $\begin{array}{l}-0.241 * * * \\
(0.000)\end{array}$ & $\begin{array}{l}-0.280 * * * \\
(0.000)\end{array}$ & $\begin{array}{l}-0.229 * * * \\
(0.000)\end{array}$ & $\begin{array}{l}-0.252 * * * \\
(0.000)\end{array}$ & $\begin{array}{l}-0.250 * * * \\
(0.000)\end{array}$ \\
\hline Dummy: Year 2003 & $\begin{array}{c}0.355^{* * * *} \\
(0.000)\end{array}$ & $\begin{array}{c}0.324 * * * \\
(0.000)\end{array}$ & $\begin{array}{c}0.385^{* * *} * \\
(0.000)\end{array}$ & $\begin{array}{c}0.362 * * * \\
(0.000)\end{array}$ & $\begin{array}{c}0.388 * * * \\
(0.000)\end{array}$ \\
\hline $\begin{array}{l}\text { Change in Real Effective Exchange } \\
\text { Rate }\end{array}$ & $\begin{array}{c}-0.011 * * * \\
(0.000)\end{array}$ & $\begin{array}{c}0.001 * * * \\
(0.008)\end{array}$ & $\begin{array}{c}-0.012 * * * \\
(0.000)\end{array}$ & $\begin{array}{c}-0.001 * * * \\
(0.004)\end{array}$ & $\begin{array}{c}-0.005 * * * \\
(0.000)\end{array}$ \\
\hline GDP Growth Rate & $\begin{array}{c}0.042 * * * \\
(0.000)\end{array}$ & $\begin{array}{c}0.045^{* * * *} \\
(0.000)\end{array}$ & $\begin{array}{c}0.042 * * * \\
(0.000)\end{array}$ & $\begin{array}{c}0.050 * * * \\
(0.000)\end{array}$ & $\begin{array}{c}0.050 * * * \\
(0.000)\end{array}$ \\
\hline Commodity Prices Growth Rate & $\begin{array}{c}-0.007 * * * \\
(0.000)\end{array}$ & $\begin{array}{c}-0.004 * * * \\
(0.000)\end{array}$ & $\begin{array}{c}-0.006 * * * \\
(0.000)\end{array}$ & $\begin{array}{c}-0.003 * * * \\
(0.000)\end{array}$ & $\begin{array}{c}-0.003 * * * \\
(0.000)\end{array}$ \\
\hline Constant & $\begin{array}{c}-3.849 * * * \\
(0.000)\end{array}$ & $\begin{array}{c}-1.681 * * * \\
(0.000)\end{array}$ & $\begin{array}{c}-3.916 * * * \\
(0.000)\end{array}$ & $\begin{array}{c}-1.655^{* * *} * \\
(0.000)\end{array}$ & $\begin{array}{c}-1.694 * * * \\
(0.000)\end{array}$ \\
\hline $\begin{array}{l}\text { Number of observations } \\
\text { Hansen Statistics (p-value) }\end{array}$ & $\begin{array}{l}2,155 \\
0.852\end{array}$ & $\begin{array}{l}3,394 \\
0.128\end{array}$ & $\begin{array}{l}2,155 \\
0.722\end{array}$ & $\begin{array}{l}3,394 \\
0.010\end{array}$ & $\begin{array}{l}5,549 \\
0.100\end{array}$ \\
\hline $\begin{array}{l}\text { Difference-in-Hansen Statistics } \\
\text { (p- value) }\end{array}$ & 0.764 & 0.342 & 0.450 & 0.014 & 0.017 \\
\hline $\mathrm{m} 1$ (p-value) & 0.000 & 0.000 & 0.001 & 0.000 & 0.000 \\
\hline m1 (p-value) & 0.806 & 0.370 & 0.560 & 0.397 & 0.746 \\
\hline Number of Instruments & 547 & 558 & 559 & 570 & 969 \\
\hline
\end{tabular}

Note: See note to Table 3. In Column 4, firms are classified as large or small based on the median of total assets by industry and year. In Columns 1 to 3, firms are classified as large or small based on the median of total assets by industry, but not by year, to avoid firms being used in both regressions if they change sizes across the years. 